\title{
Ecological patterns of phytoplankton assemblages in Lake Garda: seasonal, spatial and historical features
}

\author{
Nico SALMASO \\ Dipartimento di Biologia, Università di Padova, Via U. Bassi 58/B, I-35131 Padova, Italy \\ e-mail: nico.salmaso@unipd.it
}

\begin{abstract}
The development of phytoplankton assemblages in the two main basins of the deep $\left(Z_{\max }=350 \mathrm{~m}\right)$ and large $\left(49 \mathrm{~km}^{3}\right)$ subalpine Lake Garda (Northern Italy) was investigated through monthly samplings from 1998 to 2000. The algal development was strongly typified by the alternation, from spring to autumn, of Fragilaria crotonensis and Mougeotia sp. and by the increasing importance of filaments of the complex Planktothrix rubescens/agardhii in summer and autumn. These three "master species" are characterised by higher biovolumes and/or more regular and wide annual development in comparison to the other dominant taxa. The simultaneous application of ordination (NMDS-Non metric Multi Dimensional Scaling) and cluster analysis techniques revealed an ordered and coherent temporal succession of phytoplankton assemblages in the two main basins of the lake. These temporal and spatial regularities arise from the high inertia and resilience against perturbations that characterise the deep and large lakes, and contrast sharply with the less ordered or chaotic and unpredictable seasonal assemblages that may be found in small and shallow lakes. It is stressed that, owing to the use of different methodologies, the modifications of the phytoplankton assemblages in the last fifty years must be interpreted with particular caution. The only demonstrable differences seem to indicate that, with the speeding up of eutrophication processes in the 1960s and 1970s, detectable populations of Planktothrix and irregular increases of Conjugatophyceae (Mougeotia sp., Closterium aciculare) were established. During and after the 1980s, the increase of phosphorus concentrations in the lake and the progression towards more mesotrophic conditions was accompanied by the appearance of further substantial populations of cyanobacteria (Planktolyngbya limnetica, Anabaena lemmermannii). In contrast with these signs of alteration, Fragilaria crotonensis, Asterionella formosa, Ceratium hirundinella and Dinobryon spp. were among the most abundant taxa from the 1950s to the present time. These modifications are largely consistent with the changes observed during the 1990s in consequence of the different extent of the deep vertical mixing. During complete overturn, with the maximum spring replenishment of nutrients in the euphotic layers, a greater development of Mougeotia sp. and Oscillatoriales was observed. The historical trend and the ecological results allowed elucidation of the trophic characteristics of many important species developing in Lake Garda and, in general, in the deep subalpine lakes.
\end{abstract}

Key words: phytoplankton assemblages, annual cycles, master species, trophic evolution, Lake Garda, deep lakes

\section{INTRODUCTION}

The knowledge of the composition and abundance of phytoplankton organisms constitutes an essential feature for the assessment of the trophic status in lakes and for the evaluation of the possible or optimal utilization of different water resources. Phytoplankton closely tracks both short and long term environmental changes in lake ecosystems, so the comparison of investigations carried out in recent years with the studies made many years ago may give significant results in indicating signs of change.

The increase of algal nutrient concentrations in lakes determines a well known sequence of negative effects on water quality (Ryding \& Rast 1989; Cook et al. 1993; Harper et al. 1999). The more evident changes include an increase in plankton biomass, modification in the composition and structure of planktonic assemblages, formation of algal blooms, modification of chemical characteristics (e.g., excessive hypolimnetic oxygen consumption), decrease in water transparency and deterioration of the aesthetic appearance of water bodies. As for the utilisation of lake waters for recreational and drinking purposes, one of the main detrimental effects of eutrophication is the tendency of cyanobacteria to increase in numbers and biomass (Trimbee \& Prepas 1987; Watson et al. 1997; Ruggiu et al. 1998). These organisms are able to produce a great variety of toxic compounds (Carmichael \& Falconer 1993; Chorus \& Bartram 1999; Dow \& Swoboda 2000), so the knowledge of their ecology is an essential step towards a correct management of water resources.

However, the ultimate trophic condition in lakes derives from the interaction of a complex set of factors, including, besides nutrient concentrations and food-web relations, lake morphometry, hydrology and climatic changes. In this respect, large and deep lakes belong to a well defined typology, for they tend to function as large inertial systems, minimising the effect of external disturbances. In comparison to smaller and shallow lakes they tend to have a more regular phytoplankton development and regular internal chemical cycles due to a minor susceptibility to the influence of hydrological and meteorological events (Sommer et al. 1986; Salmaso \& 


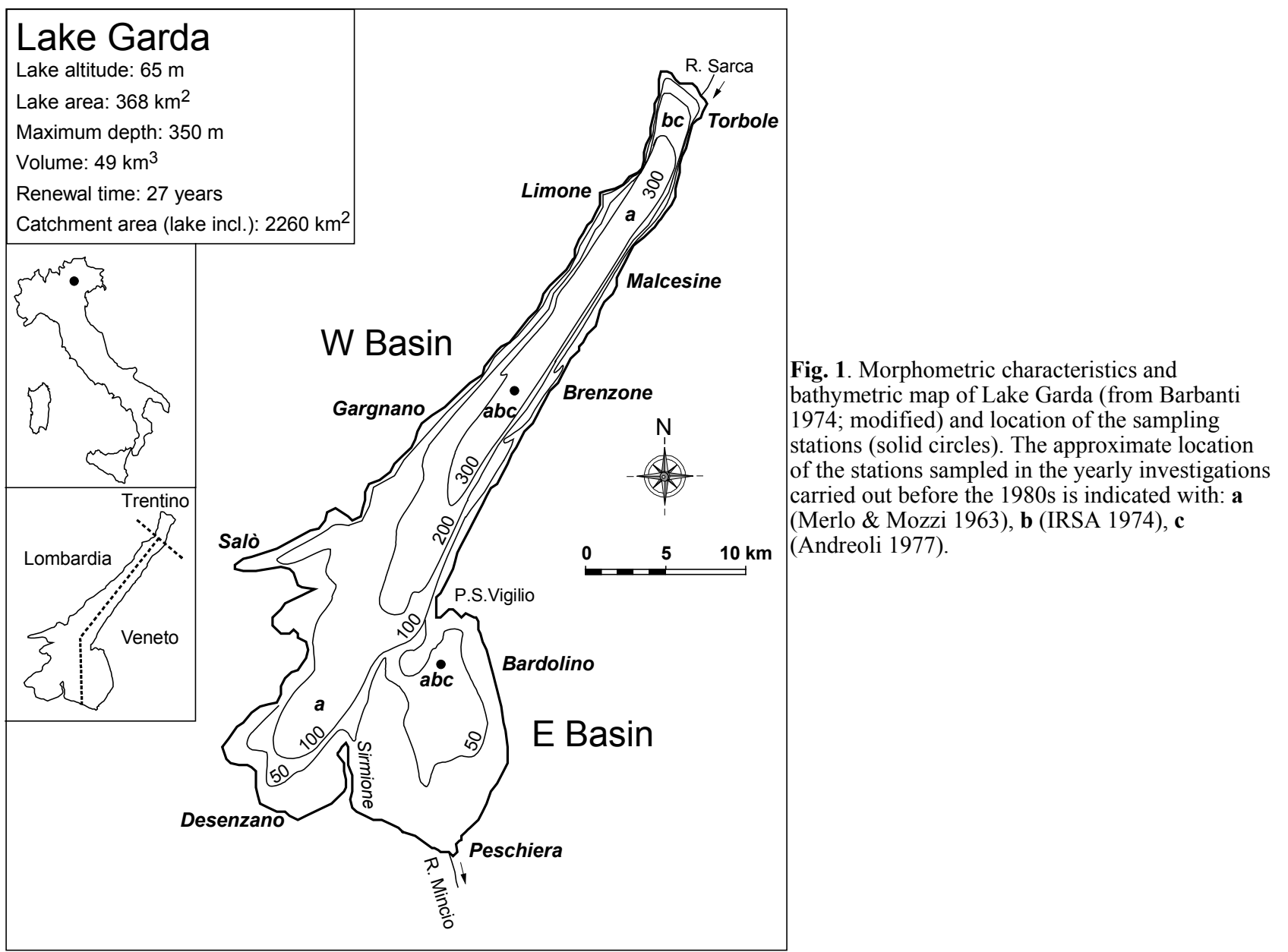

Decet 1997). As a result, large and deep lakes may be particularly suitable for detecting changes in phytoplankton assemblages due to modifications in nutrient concentrations. A further important aspect to take into account for the interpretation of phytoplankton dynamics and trophic evolution in deep lakes is represented by the extent of vertical mixing, which is dependent from weather conditions during the coldest months. This is an essential factor in the control of the fraction of nutrients potentially recyclable from the deep hypolimnetic waters (Goldman \& Jassby 1990; Salmaso et al. 2001a).

Lake Garda is the largest $\left(\mathrm{V}=49 \times 10^{9} \mathrm{~m}^{3}\right)$ of the deep lakes located south of the Alps (from east to west: Garda, Iseo, Como, Lugano and Maggiore; Ambrosetti \& Barbanti 1997). Despite its importance for recreation, tourism and drinking supply, continuous limnological studies in Lake Garda (including phytoplankton assemblages) began only recently (section 5.2). This has been due to the absence of environmental emergencies and to the apparently better water quality in comparison to the other deep southern subalpine lakes, with the effect of discouraging financial efforts aimed at the planning of water quality monitoring programs.

This paper is part of a series of contributions on the phytoplankton ecology of the deep southern subalpine lakes (Ruggiu 2002). Its main objectives are: i) to evaluate the recent composition, structure and dynamics of phytoplankton in Lake Garda; ii) to evaluate the homogeneity of the seasonal development of phytoplankton in the two major basins of the lake; iii) to compare the dominant species with those found in the earlier investigations and, finally, iv) to provide indications about the trophic range covered by the most important phytoplankters in this peculiar typology of lakes.

\section{STUDY SITE}

The bathymetric map and the main morphometric and hydrological characteristics of Lake Garda are reported in figure 1. Lake Garda is divided into two basins, separated by an underwater ridge connecting Punta $\mathrm{S}$. Vigilio with the Sirmione Peninsula. The west basin is large and deep $\left(Z_{\max }=350 \mathrm{~m}\right)$, whereas the east basin, with a maximum depth of $c a 80 \mathrm{~m}$, represents a small portion of the lake's overall volume (less than 7\%).

Lake Garda has a long water renewal time ( ca 27 years) in comparison to the other deep southern subalpine lakes (Ambrosetti \& Barbanti 1997). The main inflow is River Sarca, at the northern edge of the lake; other tributaries are of minor importance and mainly flow towards the west and north shores. The outflow, 
with an average discharge of $58 \mathrm{~m}^{3} \mathrm{~s}^{-1}$, is River Mincio, at the southern edge of the lake. Details of the catchment and the lake are reported in IRSA (1974).

\section{METHODS}

The data refer to samples collected every four weeks between January 1998 and December 2000 in two stations located in the West (Brenzone) and East Basins (Bardolino) (Fig. 1). On 4 May 1999 field samplings and measurements were carried out only at Bardolino. The average values of the chemical variables and phytoplankton abundance in the upper $20 \mathrm{~m}$ were estimated from samples collected at discrete depths.

Water samples for phytoplankton analyses were collected at the integrated depths 0-2 m, 9.5-11.5 m and 19-21 m with a $51,0.5 \mathrm{~m}$ length Niskin bottle (for a total final volume of 201 ). Chlorophyll- $a$ was determined by spectrophotometry following the methods proposed by Lorenzen (1967). The adopted procedure includes the filtration of samples (2 1) on Whatman GF-C glassfiber filters; the disruption of the filters with a grinder and $24 \mathrm{~h}$ extraction in $90 \%$ acetone; the filtration of extracts with GF-F glass-fiber filters and the measurement of the absorbance (on $5-\mathrm{cm}$ cuvettes) of the untreated and acidified $(1 \% \mathrm{HCl} \mathrm{N} / 1)$ solutions at $665 \mathrm{~nm}$ (for chlorophyll and pheophytin determination) and $750 \mathrm{~nm}$ (for turbidity correction). Subsamples of $200 \mathrm{ml}$ were fixed with Lugol's solution (Saraceni \& Ruggiu 1974) and stored in glass bottles in the dark and at $4{ }^{\circ} \mathrm{C}$ for subsequent phytoplankton analyses. Algal cells were counted using Zeiss Axiovert 135 and IM35 inverted microscopes following the criteria reported by Lund et al. (1958); for each sample, a constant volume of $10 \mathrm{ml}$ was sedimented in the counting chambers. The enumeration of the most common species was carried out, at $400 \times$, on 30 optical fields located on the bottom of the counting chamber by random computer extraction; this procedure has been adopted to guarantee a homogeneous representation of the whole area, including the marginal one. The rarest and/or largest species were determined, at $100 \times$ and $250 \times$, on greater fractions $(1 / 2-$ $1 / 5)$ of the bottom chambers. The counts were carried out by enumerating single cells and include, besides the identified fraction, ultraplankton (naked or flagellate cells around $4 \mu \mathrm{m}$ ) and undetermined nanoflagellates (around 5-10 $\mu \mathrm{m}$ ). Biovolumes were calculated from recorded abundances and specific biovolumes approximated to simple geometrical solids (Rott 1981). In general, I followed the major taxonomic subdivisions by Bold \& Wynne (1985), maintaining separately the contribution of the Chlorophyceae and Conjugatophyceae. Species identification followed the more recent monographs of the series Süßwasserflora von Mitteleuropa, established by A. Pascher, and Das Phytoplankton des Süßwassers, established by G. Huber-Pestalozzi. Chlorophytes were also identified using Bourrelly (1972). The taxonomy of Oscillatoriales was updated following
Anagnostidis \& Komárek (1988) and KomarkováLegnerová \& Cronberg (1992). The identification of Nostocales was also aided by consulting specific papers (e.g., Komarková-Legnerová \& Eloranta 1992).

Zooplankton was analysed on samples collected, from 0 to $50 \mathrm{~m}$, at Brenzone. Methods used for sampling and laboratory analyses are reported in Salmaso \& Naselli-Flores (1999).

In the first $20 \mathrm{~m}$, water samples for oxygen (Winkler titration), $\mathrm{pH}$ and conductivity measurements were collected at $0.5,10$ and $20 \mathrm{~m}$; algal nutrients were determined at 0.5 and $20 \mathrm{~m}$; water samples were stored in polythene bottles and transferred to the laboratory by means of a portable refrigerator. Conductivity (at 20 ${ }^{\circ} \mathrm{C}$ ), $\mathrm{pH}$, soluble reactive (RP) and total phosphorus (TP), nitrate $\left(\mathrm{NO}_{3}-\mathrm{N}\right)$ and ammonium nitrogen $\left(\mathrm{NH}_{4}-\mathrm{N}\right)$ and reactive silica have been measured by the Agency for the Environment Protection of the Regione Veneto (ARPAV, District of Belluno) following standard methods (APHA et al. 1989). Algal nutrient concentrations were determined on filtered samples, with exception of total phosphorus. The analytical procedures, detection limits and the precision of the analyses are described in detail by Decet \& Salmaso (1997). Temperature, pH, conductivity and oxygen measurements were carried out in the whole water column of the two sampling stations with underwater multiparameter probes.

Secchi disk transparency $\left(Z_{\mathrm{s}}\right)$ was estimated using a bathiscope to minimise uncertainties in the measurements due to light reflections at the surface and wave motions. The euphotic depth $\left(Z_{\mathrm{eu}}\right)$ was considered operationally as the depth at which $I_{\mathrm{z}}=0.01 \times \mathrm{I}_{0}$, i.e. $Z_{\text {eu }}=\ln (100) K_{\mathrm{d}}^{-1}$, where $I_{\mathrm{z}}$ and $I_{0}$ are the light intensities at the depth $Z$ and at the surface, respectively, and $K_{\mathrm{d}}$ is the vertical light attenuation coefficient (Talling 1971; Kirk 1994). Single values of $Z_{\text {eu }}$ were estimated from Secchi disk readings using the relationship $Z_{\mathrm{eu}}=4.8 \times Z_{\mathrm{s}}^{0.68}$ computed by Salmaso et al. (1997a) on the basis of a series of concurrent $Z_{\mathrm{s}}$ and $K_{\mathrm{d}}$ measurements carried out from 1992 to 1996 in the west and east basins of Lake Garda (a similar relationship, $Z_{\mathrm{eu}}=5.0 \times Z_{\mathrm{s}}^{0.70}$, may be obtained from Secchi disk readings made without a bathiscope); $K_{\mathrm{d}}$ values were estimated from irradiance profiles obtained with a submersible irradiance sensor, LiCor 192SA.

For each single sample, biovolume based Shannon diversity was estimated using natural logarithms (Magurran 1988); unidentified phytoplankton (ultraplankton and nanoflagellates) were not considered in the calculation.

Phytoplankton data were analysed by cluster analysis (average linkage method) and nonmetric multidimensional scaling (NMDS) (Kruskal \& Wish 1978; Salmaso 1996); both techniques were applied to Bray \& Curtis' dissimilarity matrices (Bray \& Curtis 1957) computed on biovolume values. Unidentified phytoplankton and rare species found on one occasion only 

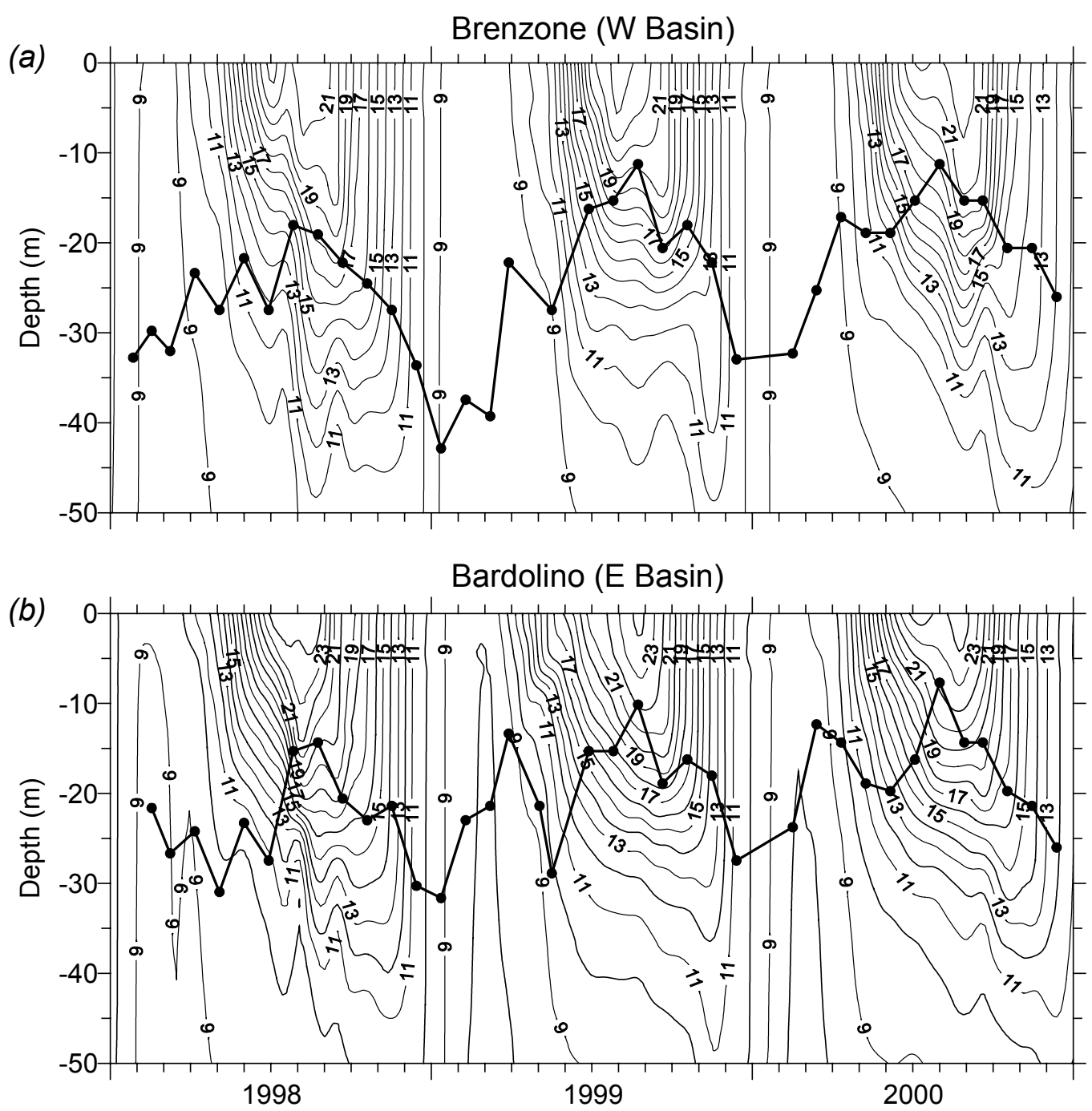

Fig. 2. Isopleths of temperatures $\left({ }^{\circ} \mathrm{C}\right)$ with superimposed seasonal variations of the euphotic depth $(\mathrm{m})$ at Brenzone (a) and Bardolino (b).

were neglected. Double square root transformation of the original data was applied to reduce the weight of the most abundant species (Field et al. 1982; Clarke \& Green 1988). The diversity and dissimilarity indices were computed with SIMDISS 2.0 (http://www.bio. unipd.it/limno/simdiss/), whereas multivariate analyses were carried out with SYSTAT 5.0 for DOS (Wilkinson 1990).

\section{RESULTS}

\subsection{Thermal structure, euphotic depth and mixing regime}

From late spring to early autumn the lake presented a marked stratification, with maximum temperatures in the first metre reaching $23-25^{\circ} \mathrm{C}$ and a maximum deepening of the metalimnetic layer down to $30-40 \mathrm{~m}$ (Fig. 2 ). The course of thermal stratification followed a similar pattern in the two stations. However, particularly in
1999 and 2000, the establishment of the thermal stability in the deepest and large west basin appeared delayed in comparison to the shallower east basin. These differences are favoured by the greater thermal inertia of the west basin and by its elongated shape, which favours the action of strong winds and wave action. In the two basins, the layer 0-20 m showed a complete thermal mixing between the end of September and October.

In the three study years the shallower east basin reached a complete isothermy between January and February. Complete vertical cooling and circulation of the west deeper basin was documented, between February and March, in 1999 and 2000 (Salmaso et al. 2001a, 2001b).

The maximum winter euphotic depths at Brenzone and Bardolino ranged between $30-45 \mathrm{~m}$ and $20-30 \mathrm{~m}$, respectively (Fig. 2). During the maximum thermal stratification, the limit of the euphotic layer at Brenzone was located at 20-25 m in 1998, and between 11-20 m 

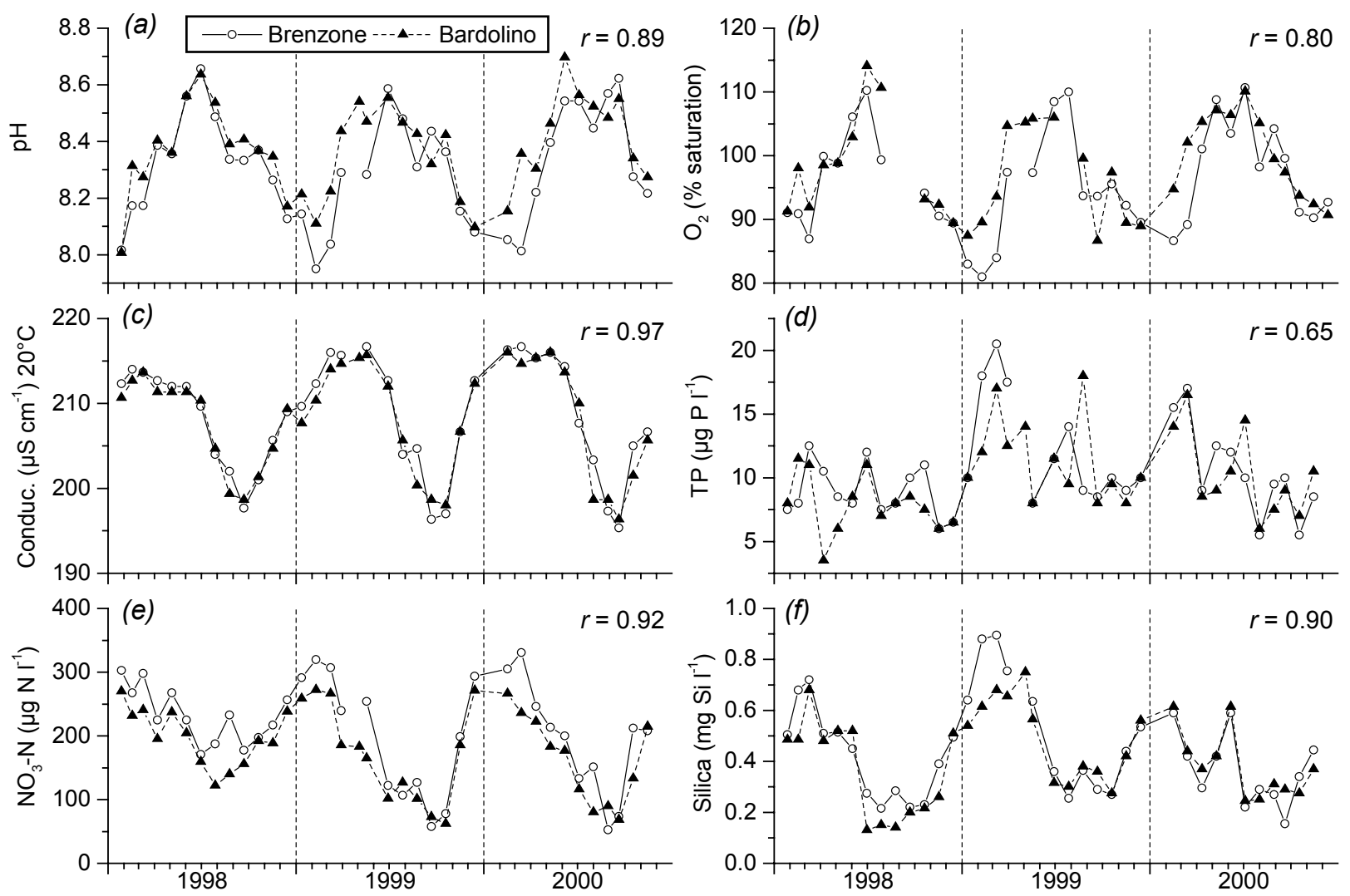

Fig. 3. Temporal variations of $\mathrm{pH}(\mathbf{a})$, oxygen (percent saturation) (b), conductivity (c), total phosphorus (d), nitrate nitrogen (e) and reactive silica (f) in the two sampling stations in the layer $0-21 \mathrm{~m}$. The correlation coefficients $\mathrm{r}$ computed between the series of data recorded in the two basins are significant at $\mathrm{P}<0.01$.

in 1999 and 2000; at Bardolino, in the same periods, the euphotic depth showed a minor extension, with values ranging between $15-20 \mathrm{~m}$ in 1998 and $7-20 \mathrm{~m}$ in 1999 and 2000. In general, the euphotic depth was similar or greater than the mixing depth $\left(Z_{\mathrm{eu}} / Z_{\mathrm{mix}} \geq 1\right)$ from MayJune to September.

\section{2. pH, oxygen, conductivity and algal nutrients}

The temporal evolution of the chemical characteristics in the epilimnetic layers followed a typical and comparable pattern in the two stations (Fig. 3). The seasonality of the chemical variables is associated to the higher phytoplankton biomass and activity during the stratification months and to the vertical mixing of the water column from late autumn to early spring (Tab. 1; cf. next sections).

Owing to their common dependence on photosynthetic processes, $\mathrm{pH}$ and oxygen (percent saturation) showed a close time correlation (Fig. 3a, b; Tab. 1). Conductivity values decreased abruptly, starting from June-July, from $210-215 \mu \mathrm{S} \mathrm{cm} \mathrm{cm}^{-1}$ to the minimum values $\left(195-200 \mu \mathrm{S} \mathrm{cm}^{-1}\right)$ recorded in September-October. The decrease of the ionic concentrations in the upper layer is linked to the precipitation of calcium car- bonate caused by algal $\mathrm{CO}_{2}$ depletion and, secondarily, by higher temperatures (Salmaso \& Decet 1998).

Higher concentrations of total phosphorus were found in 1999 and 2000 (up to 20 and $17 \mu \mathrm{g} \mathrm{P}^{-1}$, respectively) in comparison to those measured in 1998 (up to $12 \mu \mathrm{g} \mathrm{P}^{-1}$ ) (Fig. 3d). These differences have their origin in the different extent of the spring vertical mixing, which determined, in the whole basin, a major recycling of TP from the deepest layers to the surface during the two years (1999-2000) of complete overturn (Salmaso et al. 2001a, 2001b). TP shows only a weak temporal positive correlation with the other nutrients, and non significant correlations with phytoplankton abundance.

Reactive phosphorus concentrations ranged between undetectable limits and 13-17 $\mu \mathrm{g} \mathrm{P}^{-1}$ recorded during complete spring circulation at Brenzone, in 1999 and 2000, respectively. RP showed a positive temporal correlation with the other algal nutrients and negative correlations with phytoplankton abundance (Tab. 1).

Nitrate nitrogen and silica showed a clear decrease during the summer months (Figs 3e, f; Tab. 1). During the three study years, minimum values of $\mathrm{NO}_{3}-\mathrm{N}$ and silica in the 20-m layers were comprised between 
Tab. 1. Correlation coefficients (r) among the untransformed (lower-left triangular matrix) and $\log$ tranformed (upper-right triangular matrix) epilimnetic $(0-21 \mathrm{~m})$ values of $\mathrm{pH}, \mathrm{O}_{2}$ (percent saturation), conductivity, algal nutrients, Secchi disk transparency and descriptors of algal abundance (chlorophyll- $a$, phytoplankton density and biovolume) measured at Brenzone and Bardolino. The number of cases (n) is comprised between 68 and 75; figures in italics are significant at $\mathrm{P}<0.05$, the others at $\mathrm{P}<0.01$.

\begin{tabular}{lcccccccccc}
\hline & $\mathrm{pH}$ & $\mathrm{O}_{2}(\%)$ & Cond. & $\mathrm{RP}$ & $\mathrm{NO}_{3}-\mathrm{N}$ & $\mathrm{Si}$ & Secchi & Dens. & Biovol. & Chl- $a$ \\
\hline $\mathrm{pH}$ & - & 0.84 & -0.31 & -0.60 & -0.65 & -0.53 & -0.57 & 0.62 & 0.52 & 0.28 \\
$\mathrm{O}_{2}(\%)$ & 0.84 & - & n.s. & -0.50 & -0.41 & -0.46 & -0.55 & 0.58 & 0.63 & 0.47 \\
$\mathrm{Cond}$. & -0.31 & n.s. & - & 0.44 & 0.74 & 0.70 & 0.44 & -0.41 & n.s. & n.s. \\
$\mathrm{RP}$ & -0.57 & -0.49 & 0.40 & - & 0.57 & 0.50 & 0.63 & -0.56 & -0.50 & -0.36 \\
$\mathrm{NO}_{3}-\mathrm{N}$ & -0.75 & -0.52 & 0.72 & 0.59 & - & 0.61 & 0.66 & -0.69 & -0.37 & n.s. \\
$\mathrm{Si}_{\text {Sechi }}$ & -0.52 & -0.45 & 0.70 & 0.54 & 0.68 & - & 0.51 & -0.41 & n.s. & n.s. \\
Density & -0.61 & -0.59 & 0.42 & 0.64 & 0.72 & 0.60 & - & -0.73 & -0.57 & -0.54 \\
Biovolume & 0.45 & 0.37 & -0.42 & -0.36 & -0.64 & -0.34 & -0.58 & - & 0.60 & 0.44 \\
Chl- $a$ & 0.50 & 0.59 & n.s. & -0.38 & -0.42 & -0.24 & -0.53 & 0.45 & - & 0.77 \\
\hline
\end{tabular}

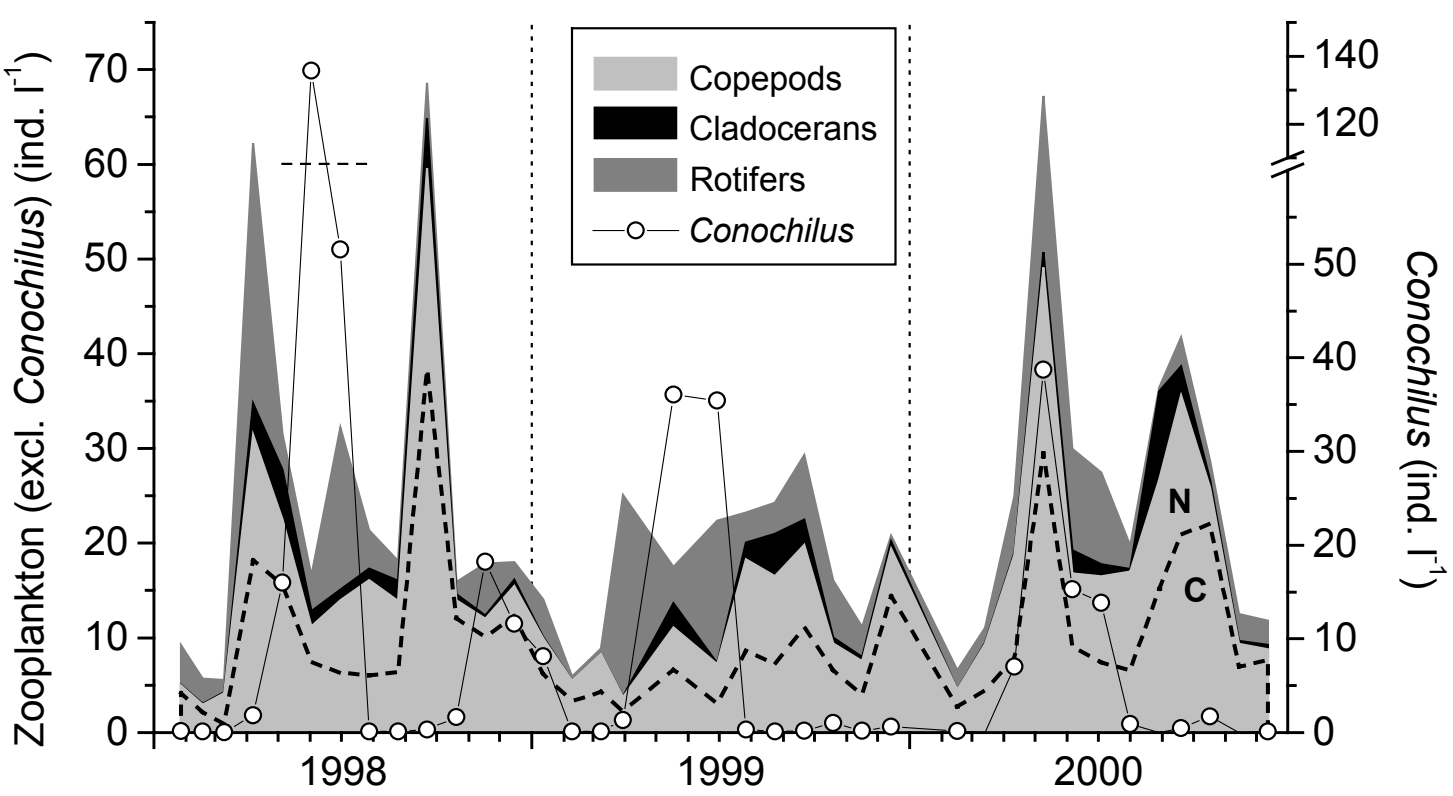

Fig. 4. Density variations of copepods (mainly Copipodiaptomus steueri), cladocerans, Conochilus and the remaining rotifers in the stations of Brenzone (0-50 m). Among copepods, the contribution of nauplii ( $\mathrm{N}$ area) and copepodites and adults $(\mathrm{C}$ area) has been highlighted.

around 50-120 $\mathrm{g} \mathrm{N}^{-1}$ and 0.1-0.2 $\mathrm{mg} \mathrm{Si}^{-1}$. A clear influence of the extent of the vertical water mixing was not evident for these two nutrients. $\mathrm{NH}_{4}-\mathrm{N}$ concentrations were always below $20 \mu \mathrm{g} \mathrm{N}{ }^{-1}$ and contributed only secondarily to the amount of the measured nitrogen pool.

\subsection{Zooplankton}

The seasonal changes of the zooplankton density are reported in figure 4. Copepods attained their maximum densities in the period from April to October. In this group, the dominant species was the calanoid Copipodiaptomus steueri, whereas the Cyclopoida were represented by few individuals of Mesocyclops leuckarti and Cyclops cf. abyssorum. Cladocera reached their maximum development from spring to early autumn. In the considered period, a clear seasonal alternation was identified among the dominant cladocerans. The Daphnia hyalina-galeata complex was present with significant densities (up to 3500 ind. $\mathrm{m}^{-3}$ in 1998) exclusively from April to mid June, whereas high seasonal densities of Diaphanosoma brachyurum were recorded only in summer (over 3000 ind $\mathrm{m}^{-3}$ ) and (with lower values) in autumn. Bosmina (Eub.) longicornis kessleri showed its maximum development (up to 4500 ind. $\mathrm{m}^{-3}$ ) in coincidence with that of Diaphanosoma, but with some irregular peaks also from April and mid June (e.g. in 1998: up to 1500 ind. $\mathrm{m}^{-3}$ ).

Owing to its large densities, the contribution of Conochilus (belonging to the C. unicornis-hippocrepis group) has been reported separately from that of the other rotifers (Fig. 4). The higher density peaks $(>30000$ 

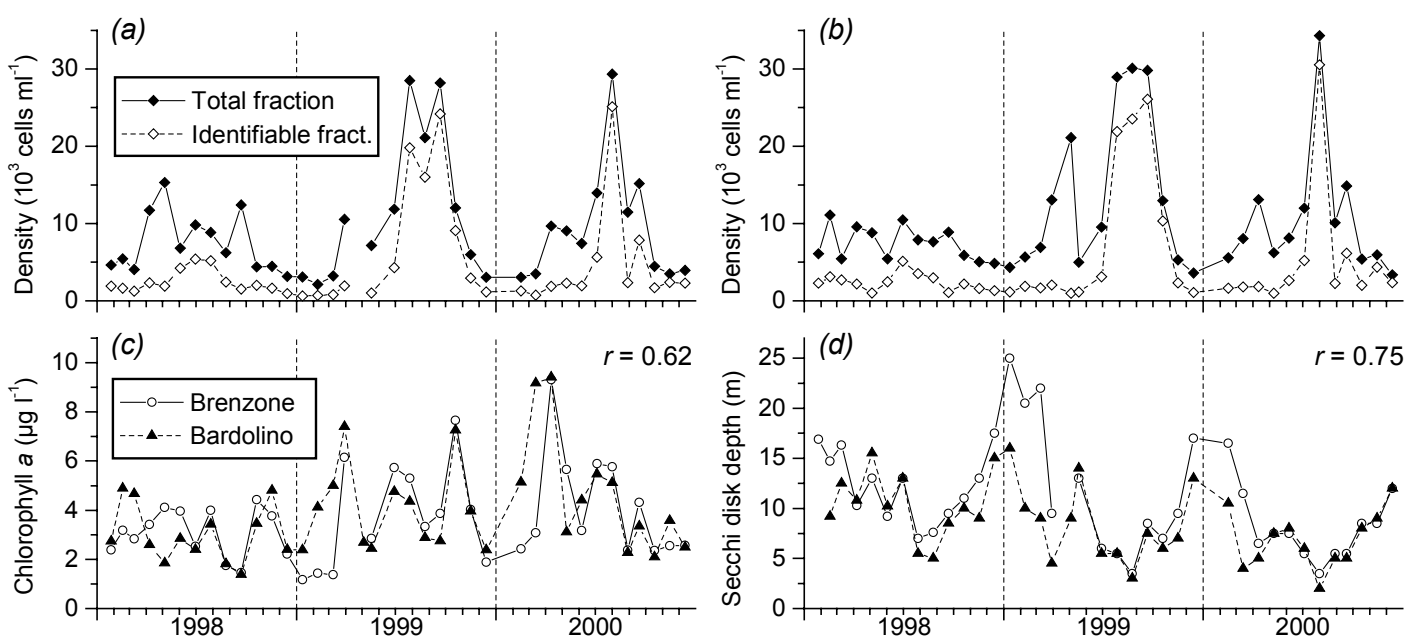

Fig. 5. Temporal variations of phytoplankton density at Brenzone (a) and Bardolino (b) in the layer 0-21 m; the total density includes the identifiable fraction, the ultraplankton and nanoflagellates; as for the total and identifiable fractions, the correlations between the single variates in the two stations are highly significant $(\mathrm{r}=0.93$ and 0.98 , respectively; $\mathrm{P}<0.01)$. The temporal variations of chlorophyll- $a(0-21 \mathrm{~m})$ and transparency in the two stations are reported in $(\mathbf{c})$ and $(\mathbf{d})$; the correlation coefficients are significant at $\mathrm{P}$ $<0.01$.

ind. $\mathrm{m}^{-3}$ ) of this species were always detected from May to June, the period of maximum development of the rotifers, which reached maximum annual densities ranging from 16000 to 28000 ind. $\mathrm{m}^{-3}$. Besides Conochilus, the more abundant rotifers included Polyarthra spp., Euchlanis cf. dilatata, Synchaeta sp., Trichocerca sp., Keratella cochlearis, Keratella quadrata and Asplanchna priodonta. The complete taxonomic list of zooplankton species and the comparison of the recent community with those found in previous studies are reported in Salmaso \& Naselli-Flores (1999).

\subsection{Phytoplankton abundance and transparency}

Figure 5 reports the temporal evolution of phytoplankton density, chlorophyll- $a$ and transparency; phytoplankton biovolumes are reported, with major details, in figure 6. During the summer months, in 1999 and 2000, phytoplankton densities reached peaks over 20000 cells $\mathrm{ml}^{-1}$ (Fig. 5a, b). These high values were mainly determined by the development of numerous Aphanothece-type colonies in 1999 (12200-19000 cells $\mathrm{ml}^{-1}$ from 27 July to 21 September) and Planktolyngbya limnetica and Aphanothece in 2000 (14700 and 6000 cells $\mathrm{ml}^{-1}$, respectively, on 1 August). The seasonal increase of density values was determined by the development of organisms with small sized cells including, besides cyanobacteria, the unidentified component made by ultraplankton with a minor contribution of nanoflagellates.

Chlorophyll- $a$ concentrations showed significant correlations with phytoplankton densities and biovolumes (Tab. 1). The highest epilimnetic concentrations were recorded during the years of complete over- turn and high replenishment of phosphorus (1999-2000) (Salmaso et al. 2001a, 2001b).

The seasonal evolution of transparency was strongly influenced by algal abundances (Tab. 1). The high Secchi disk values recorded during the winter months are due to the limited algal development in this season and to the dilution of algal particles along the water column, as consequence of mixing processes.

Total biovolume values ranged between 200 and $3050 \mathrm{~mm}^{3} \mathrm{~m}^{-3}$ (Fig. 6a, c). Owing to their modest size, the contribution of ultraplankton, nanoflagellates, Aphanothece and $P$. limnetica to biovolume values was negligible. Biovolume peaks were mainly caused by the development of single or few dominant species belonging to the Conjugatophyceae, Bacillariophyceae and Cyanobacteria (Fig. 6b, d; section 4.5).

Figure $6 \mathrm{e}$ reports a subdivision of phytoplankton biovolumes in the layer $0-21 \mathrm{~m}$ based on their susceptibility to grazing; the figure refers to the station of Brenzone, but the same results may be obtained using data collected at Bardolino. Phytoplankton come in a great variety of sizes and shapes, and the animals that feed upon them are analogously scaled and thus limited in their choices of food (Reynolds 1997). Consequently, a clear delimitation of the grazeable fraction for the entire zooplankton community is not possible. On practical grounds, in this work I distinguished four components, i.e. the edible algae (single cells or small colonies with linear dimensions <30-40 $\mu \mathrm{m}$; cf. Lehman (1988) and Lampert \& Sommer (1997)), the nearly inedible algae (organisms with dimensions $>40-50 \mu \mathrm{m}$ ) and colonies and filaments with variable size spectra, only partially or poorly edible. The colonial and filamentous algae 

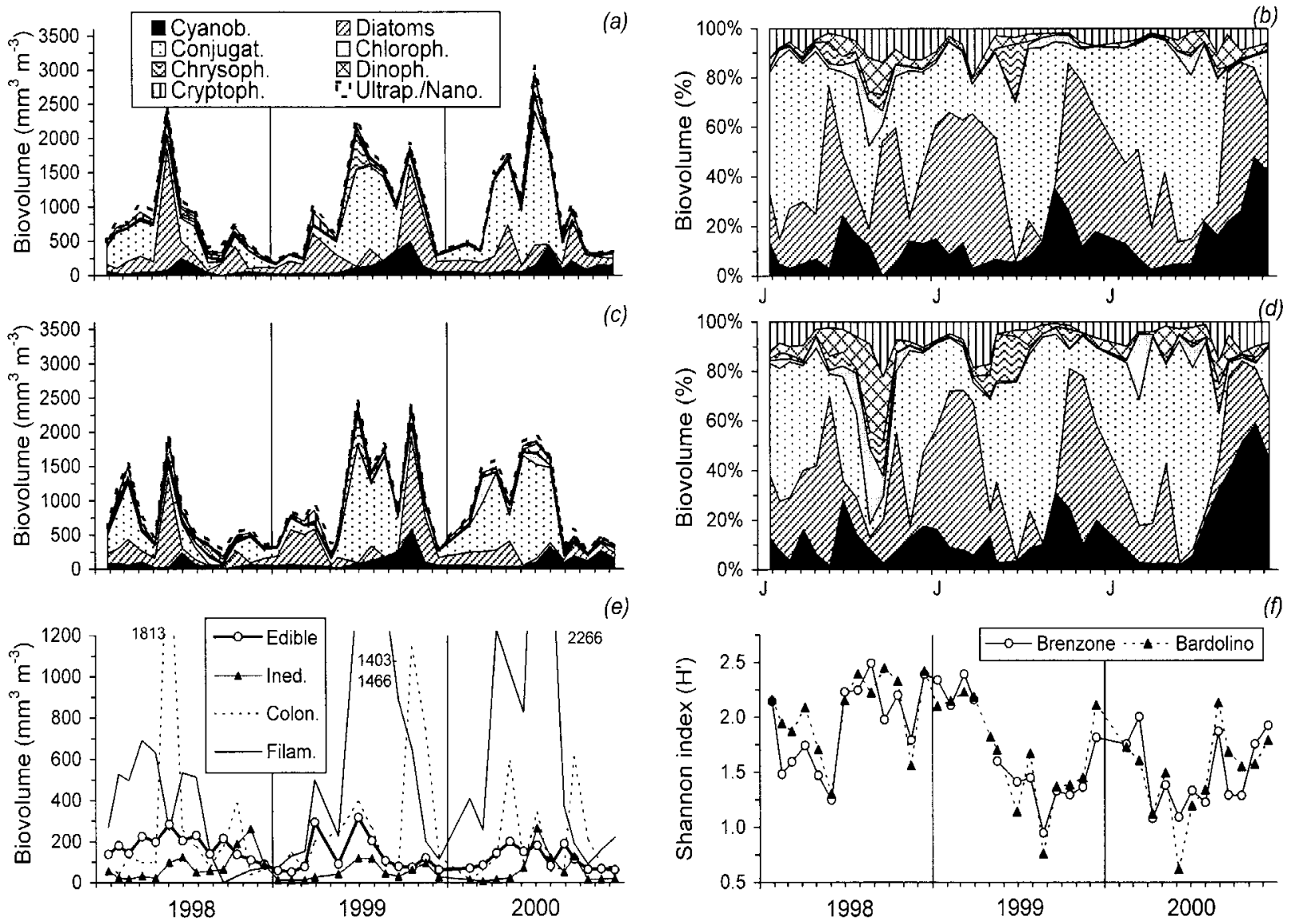

Fig. 6. Temporal variations of biovolume values subdivided by algal classes and ultraplankton/nanoflagellates, and changes in the percentage contribution of the determined phytoplankton groups to biovolume in the layer $0-21 \mathrm{~m}$ at Brenzone $(\boldsymbol{a}, \boldsymbol{b})$ and Bardolino $(\boldsymbol{c}, \boldsymbol{d})$. Biovolume variations of phytoplankton subdivided in four groups based on their susceptibility to grazing at Brenzone (e) (see explanation in the text) and temporal variations of diversity values $(f)$ in the two sampling stations.

made up the largest fraction of total biovolume. The smaller, edible algae, were most abundant during spring, with the tendency to decrease towards the end of the summer months. The inedible fraction became abundant during summer or autumn.

The largest species had a strong impact on the seasonal evolution of phytoplankton diversity (Fig. 6f). In particular, in 1999 and 2000, from late spring to the end of summer, the high development of the large Conjugatophyceae (mainly Mougeotia sp., Fig. 6a, c; cf. Fig. $7 \mathrm{a}$, next section) caused a large decrease in the diversity values.

\subsection{Seasonal development of the dominant taxa}

Table 2 reports the list of the dominant phytoplankton taxa identified, in the two stations, on the basis of relative and absolute criteria. The taxa highlighted in bold (Tab. 2b) formed a subset of the species marked in table $2 \mathrm{a}$, with the exclusion of Ulothrix sp.. Species with peaks greater than $50 \mathrm{~mm}^{3} \mathrm{~m}^{-3}$ were identified in all the considered algal groups (Tab. 2b); with few exceptions (e.g., Carteria sp.), these species showed comparable biovolume peaks in the two stations. Three species have continuously characterised, with high biovolumes, the time course of the phytoplankton development in the two stations, i.e. Mougeotia sp., Fragilaria crotonensis and filaments ascribed to the Planktothrix rubescens/agardhii group (here reported as P. rubescens/ag.; cf. Humbert \& Le Berre 2001). To underline their continuous and regular seasonal dominance in the three study years and in the preceding investigations (e.g., Salmaso 2000), these three taxa may be defined as "master species". At the other end, a few taxa were present only occasionally, in one single year. These include Melosira varians, found during the winter 1999-2000, and filamentous greens (provisionally ascribed to the Ulotrichales) identified with an isolated peak on 4 July 2000. Other species present in less than $20 \%$ of the examined dates in the two stations were small colonies of Microcystaceae, Ulothrix sp. and Dinobryon divergens. 


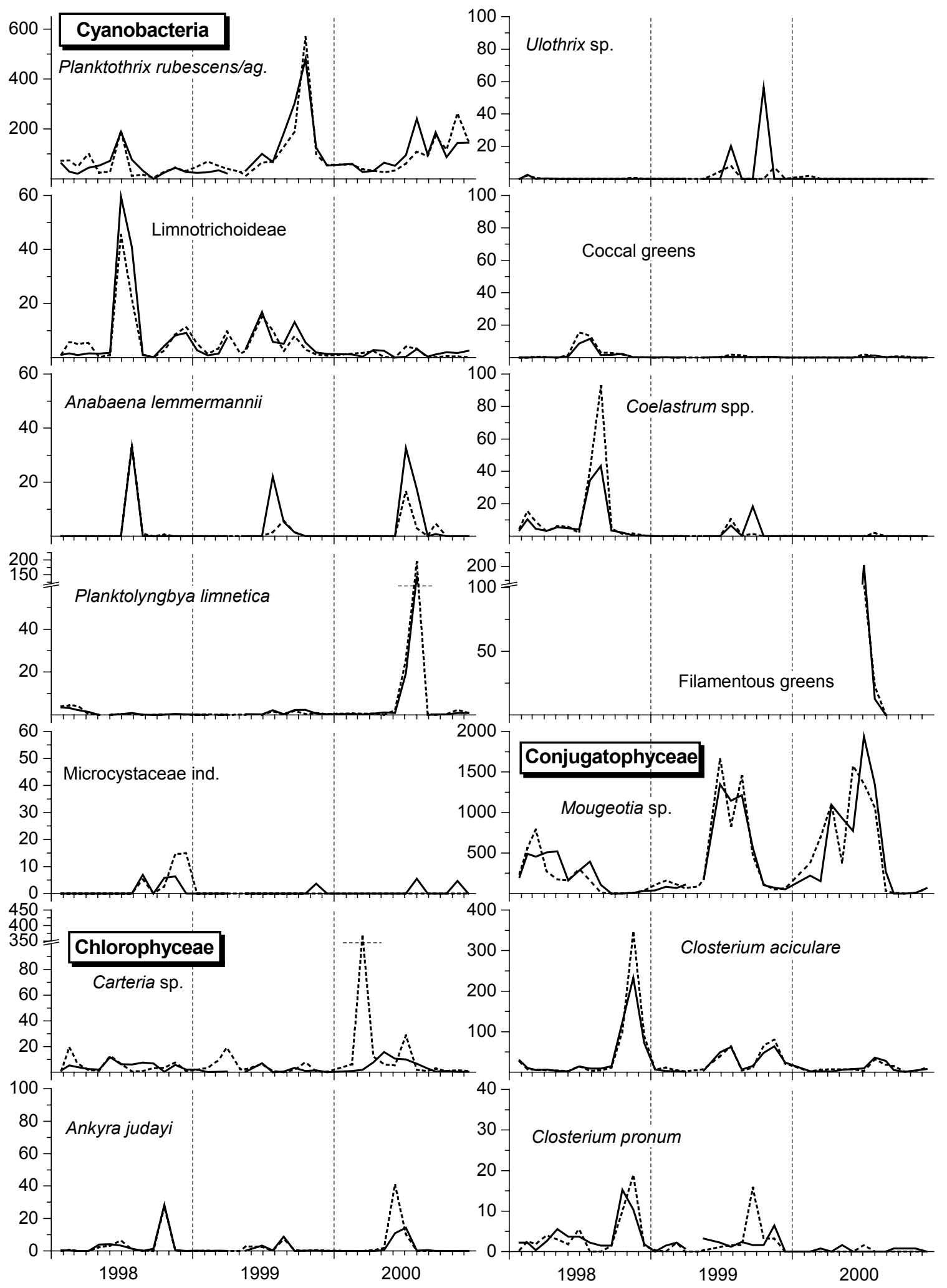

Fig. 7a. Temporal variations of biovolumes $\left(\mathrm{mm}^{3} \mathrm{~m}^{-3}\right.$ ) for the most abundant taxa (cf. Tab. 2) in the layer 0-21 $\mathrm{m}$ at Brenzone (solid lines) and Bardolino (dashed lines). Observe the higher biovolume range in the vertical axis of Planktothrix and Mougeotia (this graph) and Fragilaria (Fig. 7b) in comparison to the other species of the same algal group. 


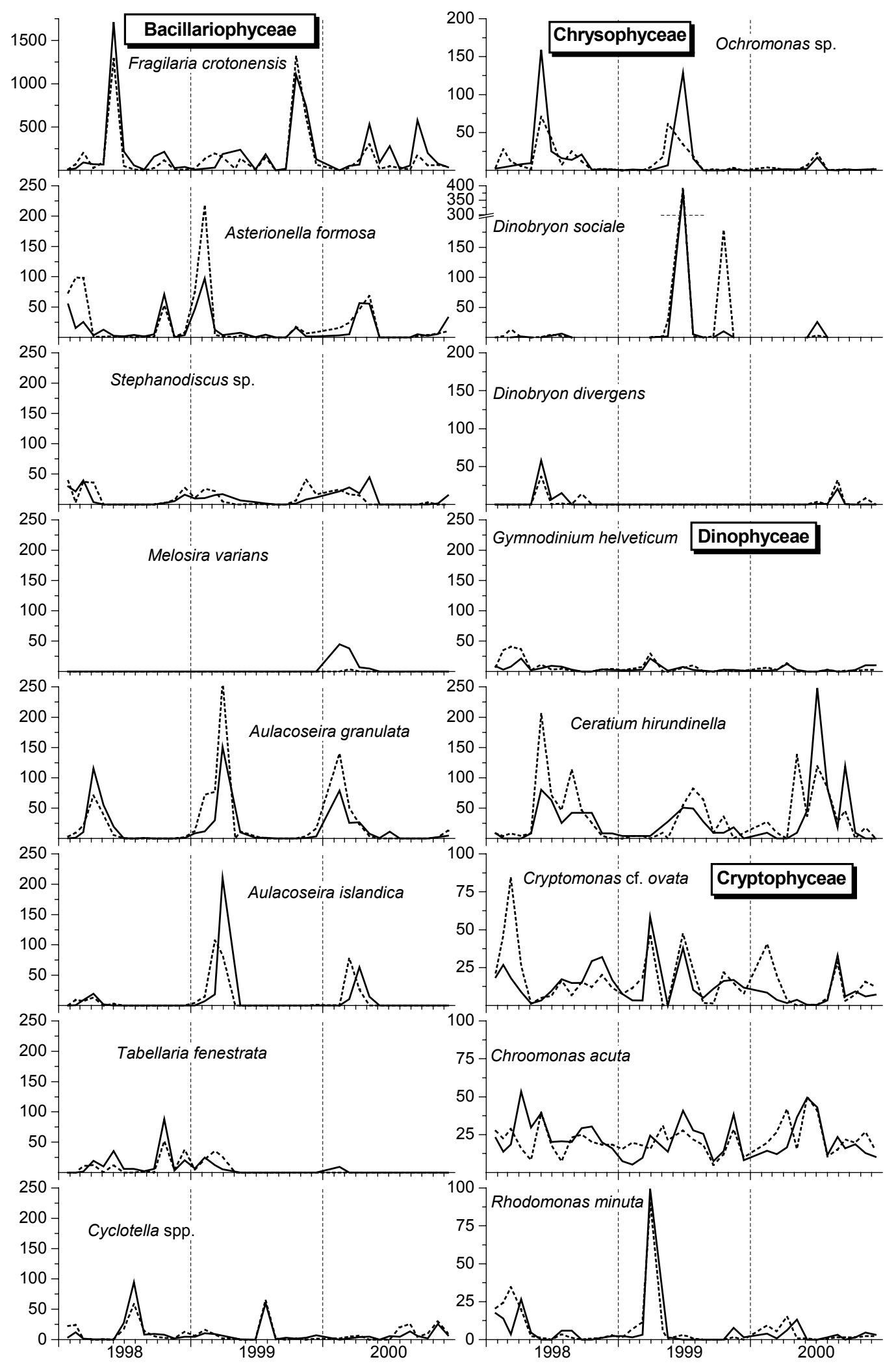

Fig. 7b. For legend see figure 7a. 
Tab. 2. Dominant phytoplankton taxa identified in the layer $0-21 \mathrm{~m}$ in the West (Brenzone) and East (Bardolino) basins of Lake Garda from 1998 to 2000. In (a) the species that, starting from the most abundant and at least in one occasion, have contributed to the $80 \%$ of the biovolume of the identified taxa (Ruggiu 1983: 107) are marked with and asterisk. Maximum biovolumes of the species are reported in (b); peaks greater than $50 \mathrm{~mm}^{3} \mathrm{~m}^{-3}$ are highlighted in bold. (c): frequency of occurrence over the whole set of sampling dates. ${ }^{(1)}$ : Planktothrix rubescens/agardhii group; ${ }^{(2)}$ : Anagnostidis \& Komárek $(1988) ;{ }^{(3)}$ : C. polychordum and C. reticulatum.

\begin{tabular}{|c|c|c|c|c|c|}
\hline & \multicolumn{2}{|c|}{ (a) } & \multicolumn{2}{|c|}{ (b) } & \multirow{2}{*}{$\frac{(\mathrm{c})}{\text { Freq. }}$} \\
\hline & Brenzone & Bardolino & Brenzone & Bardolino & \\
\hline \multicolumn{6}{|l|}{ CYANOBACTERIA } \\
\hline Planktothrix rubescens/ag. ${ }^{(1)}$ & $*$ & * & 480 & 568 & $99 \%$ \\
\hline Planktolyngbya limnetica & & * & 147 & 194 & $83 \%$ \\
\hline Limnotrichoideae $^{(2)}$ ind. & $*$ & $*$ & 60 & 45 & $96 \%$ \\
\hline Anabaena lemmermannii & $*$ & $*$ & 33 & 34 & $23 \%$ \\
\hline Microcystaceae ind. & & $*$ & 7 & 15 & $13 \%$ \\
\hline \multicolumn{6}{|l|}{ CHLOROPHYCEAE } \\
\hline Carteria sp. & & $*$ & 16 & 371 & $96 \%$ \\
\hline Filamentous greens & & $*$ & 203 & 114 & $5 \%$ \\
\hline Coelastrum spp. ${ }^{(3)}$ & $*$ & $*$ & 43 & 93 & $51 \%$ \\
\hline Ulothrix sp. & & & 57 & 8 & $15 \%$ \\
\hline Ankyra judayi & & $*$ & 28 & 41 & $57 \%$ \\
\hline Coccal greens & & $*$ & 12 & 16 & $71 \%$ \\
\hline \multicolumn{6}{|l|}{ CONJUGATOPHYCEAE } \\
\hline Mougeotia sp. & $*$ & $*$ & 1938 & 1668 & $96 \%$ \\
\hline Closterium aciculare & $*$ & $*$ & 233 & 348 & $100 \%$ \\
\hline Closterium pronum & & $*$ & 15 & 19 & $65 \%$ \\
\hline \multicolumn{6}{|l|}{ CHRYSOPHYCEAE } \\
\hline Dinobryon sociale & $*$ & $*$ & 381 & 394 & $28 \%$ \\
\hline Ochromonas spp. & $*$ & $*$ & 159 & 71 & $81 \%$ \\
\hline Dinobryon divergens & & $*$ & 58 & 37 & $19 \%$ \\
\hline \multicolumn{6}{|l|}{ BACILLARIOPHYCEAE } \\
\hline Fragilaria crotonensis & $*$ & $*$ & 1711 & 1321 & $93 \%$ \\
\hline Aulacoseira granulata & $*$ & $*$ & 151 & 260 & $65 \%$ \\
\hline Asterionella formosa & $*$ & $*$ & 97 & 218 & $80 \%$ \\
\hline Aulacoseira islandica & $*$ & $*$ & 211 & 108 & $29 \%$ \\
\hline Cyclotella spp. & $*$ & $*$ & 94 & 65 & $89 \%$ \\
\hline Tabellaria fenestrata & $*$ & $*$ & 88 & 52 & $37 \%$ \\
\hline Melosira varians & $*$ & & 45 & 3 & $7 \%$ \\
\hline Stephanodiscus spp. & $*$ & $*$ & 45 & 41 & $56 \%$ \\
\hline \multicolumn{6}{|l|}{ DINOPHYCEAE } \\
\hline Ceratium hirundinella & $*$ & $*$ & 248 & 207 & $79 \%$ \\
\hline Gymnodinium helveticum & & $*$ & 21 & 41 & $76 \%$ \\
\hline \multicolumn{6}{|l|}{ CRYPTOPHYCEAE } \\
\hline Rhodomonas minuta & $*$ & * & 99 & 91 & $75 \%$ \\
\hline Cryptomonas cf. ovata & $*$ & $*$ & 58 & 85 & $96 \%$ \\
\hline Chroomonas acuta & $*$ & $*$ & 53 & 50 & $100 \%$ \\
\hline
\end{tabular}

The seasonal development of the dominant taxa is reported in figure 7 . To highlight the temporal variations of the single species, the biovolume axes have been scaled differently according to the values reached within each algal group. The identified species showed a similar annual development in the two basins of the lake, with the exception of a very few subdominants (Anabaena lemmermannii and Carteria sp.) and occasional taxa (Ulothrix sp. and Melosira varians).

Among cyanobacteria, the annual biovolume range in $P$. rubescens/ag. was one order of magnitude greater than the other taxa (Fig. 7a). This group developed mostly in summer and autumn, with populations of Planktothrix (along with filaments of Limnotrichoideae) persisting in winter and spring. A. lemmermannii stood out for its marked periodicity, being present only during the warmest months (from late June to September), whereas Planktolyngbya limnetica, despite its high frequency (Tab. 2), was found with high biovolumes during summer 2000.

Green algae (Fig. 7a) showed a selective adaptability to different parts of the year. The only species found with irregular pulses was Carteria sp. Species belonging to the Chlorococcales (Ankyra judayi and Coelastrum spp.) and coccal greens (including mucilaginous Tetrasporales-like cells) developed mainly from late spring to early autumn. However, both Coelastrum spp. and the coccal greens were characterised by a clear decrease 
in the last two study years. Along with the other "Filamentous greens", Ulothrix sp. was present only with irregular peaks. Mougeotia sp. was a main contributor to the biovolume values from spring to early autumn. Closterium aciculare and C. pronum showed major autumn biovolume peaks.

Large diatoms were present during all the seasons, but without high peaks during the warmest months, when small Cyclotella spp. (almost all in the range 5-8 $\mu \mathrm{m})$ reached their seasonal maxima (Fig. 7b). The most abundant diatom, F. crotonensis, developed mainly during the spring or autumn months, but with irregular, significant inocula in the remaining periods. The other large species showed a regular and synchronous growth. Filaments of Aulacoseira were present almost exclusively from late winter to early spring; the occasional findings of M. varians, in 1999 and 2000, were recorded during this period. Asterionella formosa and Stephanodiscus sp. were irregularly present from late autumn to early spring. Tabellaria fenestrata was distributed from autumn to spring, but with a clear tendency to decrease during the last two study years.

Among chrysophytes (Fig. 7b), Ochromonas sp. showed regular, major peaks from May to June. On the contrary, the two species of Dinobryon occurred irregularly from spring to autumn.

Dinophytes were mainly represented by Gymnodinium helveticum (from spring to early summer or during the late autumn) and by Ceratium hirundinella (from late spring to early autumn). Among cryptophytes, Cryptomonas cf. ovata and Chroomonas acuta stood out for their irregular development, whereas seasonal peaks of Rhodomonas minuta occurred during the spring months (Fig. 7b).

\subsection{Seasonal evolution of the phytoplankton community}

The results of NMDS and cluster analysis are reported in figure 8; the analyses do not include the single sample collected on 4 May 1999 in the east station. The stress values (Kruskal \& Wish 1978) of the NMDS configurations are comprised between 0.12 and 0.15 .

In figure $8 \mathrm{a}, \mathrm{c}, \mathrm{e}$ the points corresponding to chronologically contiguous samples were united by lines in order to highlight the development with time over the two sampling stations. The cyclic character in the seasonal phytoplankton development was particularly clear in 1998 and 2000. In these two years, along the first axis of the NMDS configurations the winterearly spring samples are distinguished from those of summer, while along the second axis there is a distinction between the samples of late spring and those of late summer and/or autumn. In 1999 the distinction of the winter-early spring samples from those of summer is maintained, whereas the separation along the second axis is less evident.

By comparing the results of cluster analyses with the three configurations it is possible to identify zones of greater compositional stability. The clusters of the winter-early spring samples (groups I) and of the autumn samples (groups IV) were greater than those of the summer months, indicating, as showed also in previous works (Salmaso 1996), a higher species turnover during the stratification period. The summer (groups III) and, in 1999, the spring samples (groups II) were characterised by subgroups of different dimensions (Fig. 8).

In the defined groups the two sampling stations were always interlinked with respect to single collection dates, except May 2000, when the samples of Brenzone and Bardolino were included in two chronologically contiguous groups (Fig. 8e).

The seasonal specific assemblages are reported in Figs $8 \mathrm{~b}, \mathrm{~d}, \mathrm{f}$. The influence of the three master species Mougeotia sp., F. crotonensis and P. rubescens/ag. (Fig. 7) was evident in most groups. The changing composition of the seasonal assemblages - and their seasonal replacement - was mainly due to changes in the dominance relationships among the three master species, and by the appearance of new "seasonal species".

The distinctive feature of the winter and early spring groups (I) was the dominance of large diatoms (including, besides Fragilaria, A. formosa and A. granulata; $A$. islandica was represented, with higher biovolumes, in 1999). Another taxon typical of this period, although with lower biovolumes, was Stephanodiscus sp. (Fig. $7 \mathrm{~b})$. The contribution of Mougeotia to this group was most evident in 1998 and 2000 (Fig. 7a).

During late spring (groups II) the subdominant large diatoms decreased very much, Mougeotia and Fragilaria prevailed, small species (Ochromonas sp. and/or C. acuta) developed and the large $C$. hirundinella first appeared with high biovolumes (1998 and 2000). In 1999, the further separation of the group IIb (June) was due to the strong decrease of Fragilaria and to the development of chrysophytes (D. sociale and Ochromonas sp.) and $P$. rubescens/ag.

With the stabilisation of the water column, in the summer groups (III) F. crotonensis showed a tendency to decrease in importance (see also Fig. 7b); this species, during this period, was present only with irregular (2000: IIIb) or minor peaks (IIIa and IIIc in 1998, III in 1999 and IIIa in 2000). With the exclusion of the group IIIc (1998), the summer months showed a transition towards a community dominated by Mougeotia (particularly in 1999 and 2000), together with Planktothrix and/or Ceratium. Besides these constant components, the remaining subdominant species were variably represented. Significant taxa were Cyclotella sp. and Limnotrichoideae in 1998 (IIIa), Aphanothece spp. in 1999, and $P$. limnetica and filamentous greens in 2000 (IIIa). Despite the low biovolumes attained in the first $20 \mathrm{~m}$ (Fig. 7a), A. lemmermannii was constant in the whole summer period, when wide surface blooms were observed (cf. Salmaso et al. 1994; Salmaso 2000). 

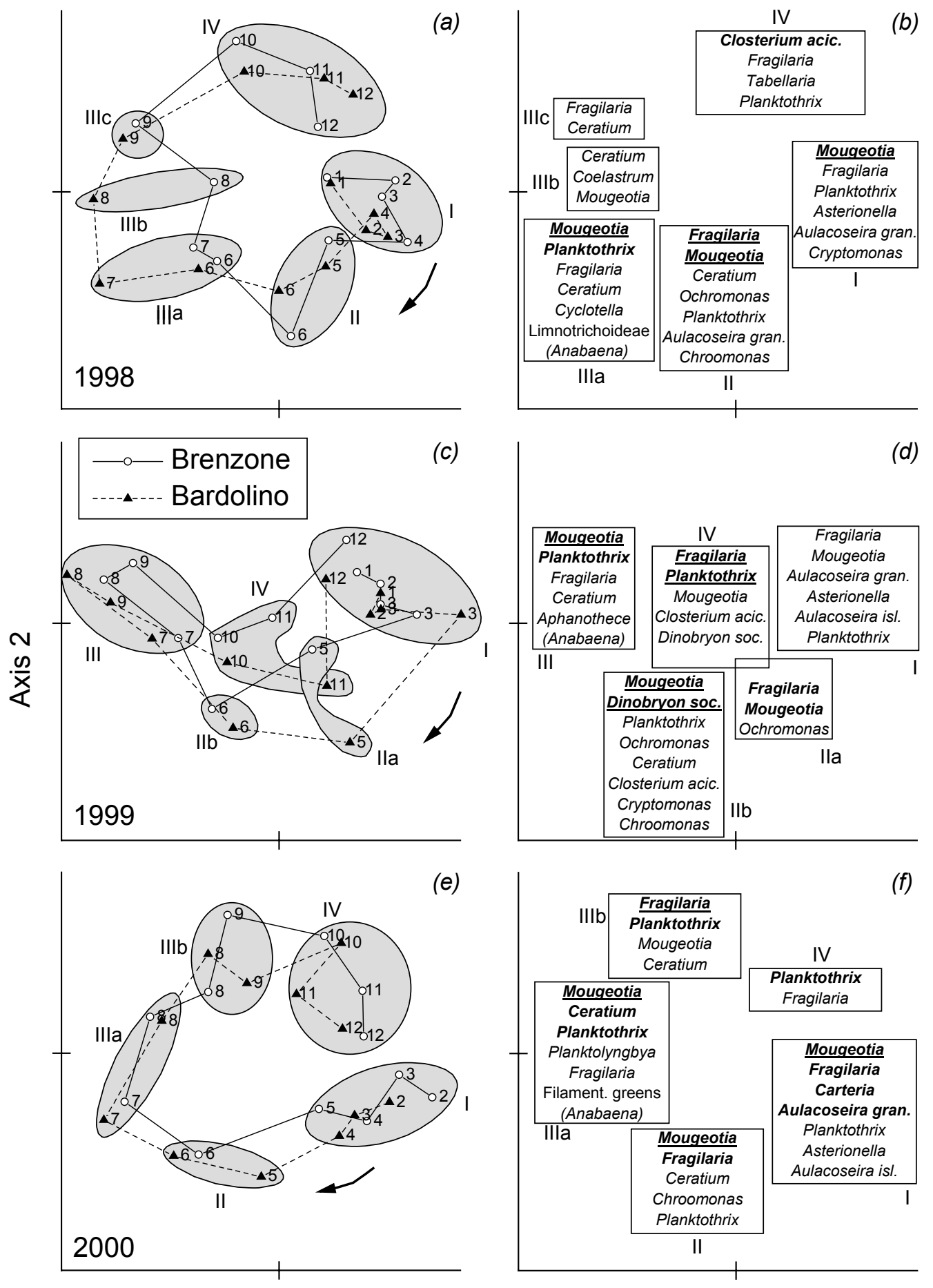

Axis 1

Fig. 8. Ordination of samples in the two-dimensional NMDS configurations $(\boldsymbol{a}, \boldsymbol{c}, \boldsymbol{e})$; the arabic numbers indicate the month of sampling. The three configurations show the groups of samples (indicated by roman numbers) identified by cluster analysis. The most abundant taxa $\left(>30 \mathrm{~mm}^{3} \mathrm{~m}^{-3}\right)$ identified on the basis of the average values of biovolume calculated separately for every single group are reported on the right panels $(\boldsymbol{b}, \boldsymbol{d}, \boldsymbol{f})$; taxa reported in lightface, bold or bold-underlined type have average biovolume values greater than 30,100 and $200 \mathrm{~mm}^{3} \mathrm{~m}^{-3}$, respectively. Species names are reported in table 2 (see explanation in the text). 
The autumn groups (IV) were characterised by the strong reduction of Mougeotia (represented only in 1999), and by the constant presence of the two master species $F$. crotonensis and $P$. rubescens/ag. Other significant species, typical of this season, are $C$. aciculare (1998-1999) and T. fenestrata (1998).

\section{DISCUSSION}

\subsection{Seasonal changes and trophic characterisation of phytoplankton assemblages}

The algal development in Lake Garda is characterised by the alternation, from spring to autumn, of Conjugatophyceae and diatoms and by the increasing importance of cyanobacteria in summer and autumn. In terms of biovolume, the phytoplankton is constantly and strongly influenced by the three master species Mougeotia sp., F. crotonensis and P. rubescens/ag..

The synchronous increase of Fragilaria and other large diatoms (Asterionella, Aulacoseira, Stephanodiscus and, partly, Tabellaria) during late winter and early spring, is a typical feature of Lake Garda, triggering the beginning of the annual phytoplankton development. However, the coexistence of the whole set of large diatoms is limited to the first 4-5 months of the year (groups I, Fig. 8), whereas colonies of Fragilaria also develop during the first stages of the water column stabilisation, with further high and irregular biomass peaks during autumn. The increase of the large diatoms with daylength at the end of winter, coincides with the high water column turbulence and high availability of nutrients at the surface during and after the spring overturn. It is known that many species become light saturated at low PAR (Sommer 1987), so that they can compete favourably with other algae in well mixed waters characterised by low $Z_{\text {eu }} / Z_{\text {mix }}$ ratios (cf. Reynolds 1984). High Si concentrations represent a positive factor for the development of diatoms because, on the coarsest taxonomic level, this algal group is the best competitor for $\mathrm{P}$ under sufficient Si supply (Sommer 1987).

The decline of large diatoms is due to the thermal stabilisation and decreased turbulence of the water column and to the exhaustion of silica (Kilham 1971; Reynolds 1997). The impact of these two factors is difficult to discriminate because high losses by sinking and mortality may override elevated growth rates, even when Si is not limiting (Reynolds 1984; Sommer 1987). The subdominant large diatoms (Asterionella, Aulacoseira and Stephanodiscus) decline during early spring, when Si concentrations are still high $\left(>0.3-0.4 \mathrm{mg} \mathrm{Si}^{-1}\right.$ Fig. 3f); thus, a negative net growth balance in this subgroup is strongly linked to increasing thermal stability and decreasing water turbulence. The decrease of Si concentration during late spring is mainly due to the growth of Fragilaria. Considering that half saturation constants for Si-limited growth are generally between $<0.1$ and $0.2 \mathrm{mg} \mathrm{Si}^{-1}$, the lowest values of silica in the layer 0-21 m from May-June to October (0.15-0.3 mg Si $1^{-1}$ ) may still support diatom growth, but to a level probably not sufficient to sustain a positive net balance in a progressively stabilised water column (Salmaso 2000); consequently, during the warmest months the development of Fragilaria is more limited and irregular. The only abundant diatoms during the stratification period and low Si concentrations are the small and light Cyclotella spp. (Fig. 7b). These diatoms are favoured by their ability to compete at low Si:P ratios with the larger pennates (Tilman \& Kilham 1976; Tilman 1977; Sommer 1987); however, the sustained growth of these small species may be inhibited by elevated grazing.

Filaments of Mougeotia sp. have their greatest growth during the spring and summer months. In 1999 and 2000 the high development of this species caused a strong decrease of phytoplankton diversity (Figs 6, 7a). The factors favouring the dominance of Mougeotia include the good competition for phosphorus and resistance to grazing and sinking. In chemostat competition experiments, Mougeotia populations from Lake Constance ( $M$. thylespora) were the most successful competitors for $\mathrm{P}$ at low $\mathrm{Si}: \mathrm{P}$ ratios among non diatoms; moreover, the field experiments carried out in Lake Constance demonstrated that Mougeotia has low sinking velocities (averages of 0.1 and $1.9 \mathrm{~m} \mathrm{~d}^{-1}$ at $0-20$ and 20$120 \mathrm{~m}$ ), i.e. up to $c a 15$ times lower in comparison to the heaviest $F$. crotonensis colonies (Sommer 1987). Filaments of Mougeotia are poorly edible by the zooplankton. Apparently, the higher development of zooplankton during spring and summer (Fig. 4) has a lower impact on the filamentous algae (Fig. 6e; mainly Mougeotia and Planktothrix), as well as on the large unicellular organisms (Ceratium) and non diatom colonies (e.g. Dinobryon, Anabaena, large Chroo- and Chlorococcales). On the contrary, grazing and micrograzing appear to be important in the density regulation of the small flagellates (Ochromonas and small cryptophytes) that characterise the spring groups (Figs 7 and 8) and in the regulation of ultraplankton, nanoflagellates and small unicellular edible species during the spring and summer months.

The abrupt decline of Mougeotia in favour of large diatoms (mainly Fragilaria) and Planktothrix at the end of summer takes place during the deepening of mixing and decreasing $Z_{\mathrm{eu}} / Z_{\text {mix }}$ ratios.

In the first $21 \mathrm{~m}$ colonies of Planktothrix become particularly important during summer and autumn (groups III and IV, respectively; Fig. 8). This taxon is well adapted to conditions of low irradiance (Reynolds 1984) and shows a clear vertical zonation during summer, with metalimnetic maxima around the limit of the euphotic zone and vertical homogenisation and dilution in autumn and winter (Salmaso 2000). This seasonal evolution is linked to the perennation strategy of Planktothrix in the deep lakes, with the autumn populations surviving in the mixing column during the succes- 
sive coldest months (Walsby et al. 1998; Micheletti et al. 1998).

Many phytoplankton species show a clear, regular and synchronous temporal evolution in the two lake basins (Fig. 7), contributing, along with the three master species, to the ordered temporal successions of phytoplankton assemblages (Fig. 8). During the three study years, the groups identified during mixing conditions (groups I) and, partly, during the destratification of the water column (groups IV) are more clearly typified than the late spring and summer groups. This indicates the importance of such physical factors in determining a clear ending of the summer phytoplankton development, and a new beginning, with a pool of species similar from year to year starting a new annual cycle. On the other side, environmental constraints during the warm and stratified months are also determined by plankton growth and metabolism, including exhaustion of nutrients, phytoplankton grazing, nutrient recycling and selfshading. This would determine an increasing complexity in the pelagic food web and major niche differentiation, and influence the number and size of the phytoplankton groups during late spring and summer. However, the temporal evolution of seasonal assemblages follows a similar path, with a limited number of mutually alternative dominants.

Groups I and IV correspond to some extent to the classification of phytoplankton assemblages given by Reynolds (1997). The large spring diatoms in groups I may be associated to the assemblage classified as type $\mathrm{C}$, represented in productive and mostly temperate lakes and comprising Fragilaria, Asterionella, Stephanodiscus and Aulacoseira. The occurrence of Fragilaria and Closterium in the autumn groups (IV) in 1998 and 1999, may be ascribed to Association P, which is considered typical of temperate eutrophic lakes where Association $\mathrm{C}$ is also represented. During spring the nanoplanktonic taxa (Ochromonas, the small cryptophytes and Ankyra) may conform to the eutrophic Associations X (X1, X2), whereas Dinobryon belongs to the Association E. Mougeotia sp., the most typical species developing during the late spring and summer months in Lake Garda, has been placed in the Association T, including filamentous algae (e.g. Ulotrichales, Conjugatophyceae, Tribonema). Examples of dominance of planktonic populations of Mougeotia have been reported for various deep subalpine lakes (e.g. Ruggiu \& Mosello 1984; Sommer 1987; Salmaso 2000). Members of this genus, living in this peculiar type of lakes and able to successfully compete in a "completely pelagic" environment during stratified conditions, may be considered as part of a circumscribed group. Although present only with irregular pulses, the remaining two filamentous greens (Ulothrix sp. and the filaments provisionally ascribed to the Ulotrichales) may be considered as an integral part of this assemblage. During summer and/or autumn, the filaments of the third master species $P$. ru- bescens/ag. and of the subdominant $P$. limnetica conforms to Association R, which includes the Oscillatoriales living in deep lakes. During summer, other associations may be represented with at least one subdominant species. These include constantly (cf. Fig. 8b) the Associations $\mathrm{H}$ and $\mathrm{L}$ (A. lemmermannii and $C$. hirundinella, respectively) and, more irregularly, the Associations $\mathrm{K}$ and $\mathrm{S}$ (Aphanothece spp. and Limnotrichoideae, respectively), J (Coelastrum spp.and other coccal greens) and A(?) (small Cyclotella spp.).

Many of the Associations identified are considered indicative of nutrient rich lakes. As for the dominant groups $\mathrm{C}$ and $\mathrm{P}$ (and the subdominant $\mathrm{X}$ ) this may correspond to the peculiar properties of the deep temperate lakes, characterised by spring and autumn enrichment of nutrients by mixing. On the contrary, the absence of significant external inputs of nutrients during the stratification months, with the growth requirements essentially fulfilled by recycling, storage and N-fixation (Nostocales), may explain the subdominant character of the other "eutrophic" Associations, namely J and H. In particular, the low summer concentrations of $\mathrm{P}$ seem to control the surface blooms of $A$. lemmermannii occurring every year in Lake Garda; at present, owing to the strict location of the colonies in the first centimeters of the water column, with low overall biovolumes in the first two metres (cf. Fig. 7a), these episodes are classified as oligotrophic blooms (Salmaso 2000). The results obtained in Lake Garda would indicate that these "eutrophic" groups, in this typology of lakes, may be represented also in oligo-mesotrophic conditions. However, in a recent paper, Reynolds et al. (2002) separated the eutrophic group H1 (Aphanizomenon flos-aquae, Anabaena flos-aquae, A. circinalis and A. spiroides) from the group of species (H2), such as A. lemmerman$n i i$, that are typical of larger and less eutrophic lakes. The subdominants Ceratium (L) and Dinobryon (E) are considered eurytrophic or typical of mesotrophic lakes, respectively; on the other hand, group $\mathrm{E}$ is sensitive to nutrient enrichment and $\mathrm{pH}$ (Reynolds 1997; Reynolds et al. 2002).

Representatives of the genus Planktothrix (R) are potentially able to inhabit waters over a wide range of trophic status (Reynolds 1984). P. rubescens is a common cyanobacterium in the deep southern subalpine lakes, but it shows a clear increase towards higher TP concentrations (Salmaso 2000; see also 5.2).

Table 3 reports the trophic parameters used by OECD (1982) for the trophic characterisation of lakes, along with the annual averages of phytoplankton biovolume. In 1998, in both stations, the considered parameters indicate intermediate conditions between oligotrophy and mesotrophy. In 1999 and 2000, with the complete overturn of the lake, the same parameters indicate a shift towards more mesotrophic conditions. The decrease of transparency and the increase of chlorophyll- $a$ concentrations in 1999-2000 is parallelled by an 
Tab. 3. Trophic parameters used by OECD (1982) for the trophic characterisation of lakes (minimum values of Secchi disk depth, maximum concentrations of chlorophyll$a$, annual average concentrations of chlorophyll- $a$ and TP) and annual averages of phytoplankton biovolumes computed for the stations of Brenzone (a) and Bardolino (b) between $0-21 \mathrm{~m}$.

\begin{tabular}{lcccccccc}
\hline & \multicolumn{3}{c}{$\begin{array}{c}\text { (a) } \\
\text { Brenzone }\end{array}$} & & \multicolumn{3}{c}{$\begin{array}{c}\text { (b) } \\
\text { Bardolino }\end{array}$} \\
\cline { 2 - 4 } \cline { 7 - 9 } & 1998 & 1999 & 2000 & & 1998 & 1999 & 2000 \\
\hline Secchi disk, minimum $(\mathrm{m})$ & 7.0 & 3.5 & 3.5 & & 5.0 & 3.0 & 2.0 \\
Chlorophyll- $a$, average $\left(\mu \mathrm{g} \mathrm{l}^{-1}\right)$ & 3.1 & 3.7 & 4.1 & & 3.0 & 4.0 & 4.6 \\
Chlorophyll- $a$, maximum $\left(\mu \mathrm{g} \mathrm{l}^{-1}\right)$ & 4.4 & 7.7 & 9.3 & & 4.9 & 7.4 & 9.4 \\
Total phosphorus, average $\left(\mu \mathrm{g} \mathrm{P} \mathrm{l}^{-1}\right)$ & 9 & 12 & 11 & & 8 & 11 & 10 \\
Total biovolume, average $\left(\mathrm{mm}^{3} \mathrm{~m}^{-3}\right)$ & 845 & 1059 & 1103 & & 794 & 1092 & 1031 \\
\hline
\end{tabular}

increase in the annual average values of biovolume. The importance of spring circulation in fertilising epilimnetic waters in deep lakes was statistically confirmed analysing the whole set of data available since 1991 (Salmaso et al. 2001a, 2001b). The results showed an evident impact of lake volumes involved at spring overturn on the trophic variables, with positive effects on epilimnetic phosphorus, chlorophyll- $a$, total algal biovolumes and cyanobacteria, and negative effects on water transparency. Consequently, during the 1990s the trophic state oscillated between oligo-mesotrophy and mesotrophy. Similar conclusions were obtained from a subset of phytoplankton data recorded at the surface (0.5 or $0-2 \mathrm{~m}$ ) from 1991 to 1995 (Salmaso et al. 1999). As for 1999 and 2000, and among the three master species, the effect of the positive impact of complete overturn was particularly evident for Mougeotia and, partly, for Planktothrix (Figs 6 and 7a). Mougeotia, in particular, was more persistent, with high biovolumes also until the late summer months of 1999 and 2000. These natural experiments of mild P-enrichment suggest a dependence of the continuous and sustained summer growth of Mougeotia on an adequate replenishment of nutrients during spring overturn.

\subsection{Modifications along the historical trophic gradient}

The present mesotrophic or oligo-mesotrophic character of Lake Garda contrasts with its original oligotrophic status; in fact, at the end of the $19^{\text {th }}$ century this lake was characterised by a very low abundance of fish (meschinissima, i.e. very miserable) and the objective of lake biology was judged instrumental for the definition of the remedies to assure a sufficient catch and means of subsistence to fishermen (Garbini 1898). The work of Guilizzoni et al. (1983), on the palaeolimnology of some northern Italian lakes, estimated, for a period around the beginning of the last century, a very low annual production for Lake Garda, indicative of oligo- or ultra-oligotrophic conditions. The long-term studies carried out from the 1970s showed an increase of the phosphorus content in the water column, with concentrations of TP generally below or around $12 \mu \mathrm{g} \mathrm{P}^{-1}$ in the $1970 \mathrm{~s}$ and mid $1980 \mathrm{~s}$, and $17-20 \mu \mathrm{g} \mathrm{P}^{-1}$ at the end of the 1990s (Calderoni et al. 1997; Salmaso et al. 1997b, 2001a). This increase parallels the resident population rise and the strong development of tourism; the number of days spent by tourists in the lake district has progressively increased, from 2-3 million days $\mathrm{y}^{-1}$ in the 1960 s to over 15 million days $\mathrm{y}^{-1}$ in the second half of the 1990s (Pasini 1992, and data of the "Comunità del Garda"). The changes in the phytoplankton community along the trophic time gradient are difficult to report because of the scarcity of the available works and of the different methodologies adopted in the field and laboratory, especially if the investigations before the 1970s are considered.

Before the continuous research started at the end of the 1980s (e.g., Negri \& Morazzoni 1990; Cordella \& Salmaso 1993; Büsing 1998), the only investigations on the phytoplankton organisms, covering the whole year and including nannoplanktonic fractions, were carried out from December 1970 to March 1972 by IRSA (1974) and from September 1972 to August 1973 by Andreoli (1977) (Fig. 1). Other observations, but based on samples collected during the maximum spring overturn and during autumn stratification, were made from 1978 to 1981 by Ruggiu (1983) and Ruggiu \& Mosello (1984). In the 1950s phytoplankton was studied on netplankton samples; D'Ancona et al. (1961) and Merlo \& Mozzi (1963) carried out their research in one year cycle (February 1957-January 1958) (Fig. 1), whereas the work of Marchesoni (1952) is based on one series of samples collected, during September 1951, on 7 stations covering the whole lake. Observations made in the late nineteenth century, consisted exclusively of qualitative inventories of algal taxa found in the lake and along the littoral (phytoplankton and periphyton) (Garbini 1898; Kirchner 1899; Forti 1902).

In the work of IRSA (1974), the phytoplankton abundance (density) was reported in detail only for a limited subset of species at 8 discrete depths between 0 $20 \mathrm{~m}$ and at $30 \mathrm{~m}$. The maximum individual densities of other species were expressed as $\log _{10}$ and approximated to the unity by defect; in this case, the comparison is possible only considering abundance intervals. Andreoli (1977) reported maximum density values only for some dominant taxa (Planktothrix, Microcystis, Mougeotia, 
Tab. 4. Comparison list of the estimated maximum peaks of phytoplankton biovolumes $\left(\mathrm{mm}^{3} \mathrm{~m}^{-3}\right)$ recorded at discrete sampling depths during 1998-2000 and at the beginning of the seventies in various stations of the lake (Fig. 1). (i): IRSA (1974); (ii): Andreoli (1977). "+" and "-" indicate presence and absence, respectively. ${ }^{(1)}$ : see Salmaso et al. $(1994) .{ }^{(2)}: E$. elegans; single, isolated peak recorded at Torbole; ${ }^{(3)}$ : reported as A. gracillima; ${ }^{(4)}$ : average value from discrete samples from 0 to $50 \mathrm{~m}$ (See explanation in the text).

\begin{tabular}{|c|c|c|c|c|}
\hline & $\begin{array}{l}\text { XII.1970-III.1972 } \\
\text { (i) }\end{array}$ & $\begin{array}{l}\text { IX.1972-VIII. } 1973 \\
\text { (ii) }\end{array}$ & $\begin{array}{l}\text { I.1998-XII.2000 } \\
\text { (this work) }\end{array}$ & \\
\hline \multicolumn{5}{|l|}{ CYANOBACTERIA } \\
\hline Planktothrix rubescens/ag. & 578 & 440 & 710 & $=$ \\
\hline Planktolyngbya limnetica & - & - & 249 & $\uparrow$ since the eighties \\
\hline "Microcystis" spp. & 212 & 440 & 37 & $(*)^{(1)}$ \\
\hline Anabaena lemmermannii & - & - & oligotrophic lake blooms & 个since the nineties \\
\hline \multicolumn{5}{|l|}{ CHLOROPHYCEAE } \\
\hline Carteria sp. & - & - & 1104 & $*(\uparrow)$ \\
\hline Filamentous greens & - & - & 217 & $*(\uparrow)$ \\
\hline Eudorina sp. & $300-3000^{(2)}$ & + & 2 & $?$ \\
\hline \multicolumn{5}{|l|}{ CONJUGATOPHYCEAE } \\
\hline Mougeotia sp. & $25-250$ & 1870 & 3370 & $(=\uparrow)$ \\
\hline Closterium aciculare & $3-29$ & - & 374 & $*(\uparrow)$ \\
\hline \multicolumn{5}{|l|}{ CHRYSOPHYCEAE } \\
\hline Dinobryon spp. & $9-86$ & + & 1145 & * \\
\hline Ochromonas spp. & $150-1500$ & - & 426 & $=$ \\
\hline \multicolumn{5}{|l|}{ BACILLARIOPHYCEAE } \\
\hline Fragilaria crotonensis & 1400 & 3800 & 2915 & $=$ \\
\hline Aulacoseira granulata & - & 320 & 404 & $\uparrow$ since the seventies (?) \\
\hline Aulacoseira islandica & - & - & 307 & $\uparrow$ since the end of the seventies (?) \\
\hline Asterionella formosa & 145 & $t^{(3)}$ & 228 & $=$ \\
\hline Cyclotella spp. & $10-107$ & + & 214 & $=$ \\
\hline Melosira varians & $50-500$ & + & 134 & * \\
\hline Tabellaria fenestrata & $3-28$ & $c a 600^{(4)}$ & 122 & * \\
\hline \multicolumn{5}{|l|}{ DINOPHYCEAE } \\
\hline Ceratium hirundinella & $50-500$ & + & 690 & $=$ \\
\hline
\end{tabular}

Fragilaria and A. granulata); moreover, he reported in graphs the temporal evolution of the average density values in the layer 0-50 $\mathrm{m}$ of Planktothrix, Fragilaria, Tabellaria and Mougeotia. After calculating new biovolume values from density, multiplied by specific biovolumes, I compared the results reported in these earlier works with the maximum biovolumes recorded in the layers 0-2, 9-11 and 19-21 $\mathrm{m}$ at Brenzone and Bardolino, between 1998 and 2000 (Tab. 4). The comparison is based only on the most abundant species, with biovolume peaks greater than $200 \mathrm{~mm}^{3} \mathrm{~m}^{-3}$. Of the three master species recognized in the present work, $F$. crotonensis and P. rubescens/ag. in the first half of the 1970 s showed biovolume peaks comparable with those found in 1998-2000 and, in general, during the 1990s. As for Mougeotia, the available data seem to indicate a large inter- (Tab. 4) and intra-annual variability, with maximum values lower than those found in 1998-2000. In particular, in the work by Andreoli (1977), the temporal evolution of Mougeotia in the layer 0-50 m (average values from discrete depths) was characterised by a single peak of $c a 950 \mathrm{~mm}^{3} \mathrm{~m}^{-3}$ in October, whereas, in the remaining months, the values were always below $\mathrm{ca} 120$ $\mathrm{mm}^{3} \mathrm{~m}^{-3}$. Other differences with the recent period are the finding of Aulacoseira (formerly Melosira) islandica (Ruggiu 1983) during the end of the 1970s ( $A$. granulata was identified during the same decade; cf. Andreoli 1977), and the occurrence and increasing importance of the cyanobacteria $P$. limnetica (Negri \& Morazzoni 1990) and A. lemmermannii (Salmaso et al. 1994) during the 1980s and 1990s. The differences between the two considered periods for the species marked with an asterisk in table 4 are more difficult to interpret. In the present work, Carteria sp., C. aciculare and $T$. fenestrata were characterised by high interannual variability, whereas the undetermined filamentous greens and M. varians appeared abruptly, in single years (cf. Fig. 7). Dinobryon was found in 1971 with localised blooms in the northern part of the east basin, despite the low biovolume peaks determined during the same year in the usual sampling depths (IRSA 1974). The great biovolume values reached in the first $50 \mathrm{~m}$ by Tabellaria in May 1973 are noteworthy, suggesting a great potential growth of this species 30 years ago in comparison to the period from 1995 to 2000 (Fig. 7b, Tab. 4 and Salmaso 2000). Further differences with the present are the high abundances reported for the colonial Volvocaceae during the 1970s: these include the peak of Eudorina elegans recorded near Torbole (IRSA 1974; Tab. 4) and an important ("principal") contribution of Volvox globator to the biovolume of Chlorophyceae (Andreoli 1977). Colonies of Eudorina sp. were found 
during the $1990 \mathrm{~s}$ with a peak of $460 \mathrm{~mm}^{3} \mathrm{~m}^{-3}$ (July 1994; N. Salmaso, unpublished data), whereas Volvox was never detected; however, owing to the absence of quantitative data and the larger strata of water sampled by Andreoli (1977) (up to $300 \mathrm{~m}$ ), the significance of the presence of this taxon in the 1970s remains problematic.

The comparison with the older observations of the 1950s must be carried out with great caution, and only for the larger organisms. Quantitative differences cannot be estimated, and only qualitative assessment on netphytoplankton may be evaluated. The dominant species indicated by D'Ancona et al. (1961) and Merlo \& Mozzi (1963) were $F$. crotonensis, A. gracillima $(=A$. formosa), $C$. hirundinella and Dinobryon spp. These taxa were included among the most abundant species also by Marchesoni (1952). Moreover, Merlo \& Mozzi (1963) mentioned the occasional findings of genera and species that, at present, are found in the usual phytoplankton samples (Aphanocapsa, Mallomonas, Cyclotella, Melosira, Synedra and Tabellaria) or, occasionally, in net- or benthic samples (Botryococcus braunii and Surirella, respectively). Compared with the studies carried out in the 1970s (IRSA 1974), the primary difference is the lack of the two master species $P$. rubescens/ag. and Mougeotia sp.; a further difference is the absence of the genus Closterium among the larger subdominants. The identification of large populations of P. rubescens/ag. in Lake Garda after the 1960s parallels or follows the strong development of this species in other deep southern subalpine lakes with the beginning of eutrophication during the 1970s (Lake Iseo; Ruggiu 1983), the 1960s (Lake Maggiore; Ravera \& Vollenweider 1968; Ruggiu 1989) and the 1950s (Lake Lugano; Polli \& Simona 1992). The absence of the two conjugatophytes in the samples collected during the 1950 s is more difficult to interpret. An unsuccessful recovery of Mougeotia or C. aciculare from net samples is unlikely; at present, these two taxa, along with Planktothrix, are among the most abundant organisms concentrated during the filtration of samples for zooplankton examinations through nets of $80 \mu \mathrm{m}$ mesh. However, these two conjugatophytes were identified in the littoral plankton and benthos of Lake Garda at the end of the 1800s by Kirchner (1899). Even considering the results obtained during the 1950 s with due reservation, the available data appear to indicate a progressive increase of Mougeotia and Closterium from the beginning of the eutrophication up to the mesotrophic maximums reached during 1999-2000. It is interesting to observe that, in Lake Maggiore, Mougeotia sp. was identified in the 1950s, but it attained appreciable abundances only from the 1970s (Ruggiu 1989; Ruggiu et al. 1998). In Lake Lugano, research at the beginning of the 1900s failed to reveal either Mougeotia sp. or C. aciculare; after the 1950s these two species maintained constant levels, but with Mougeotia characterised by a ma- jor variability after 1988 (Polli \& Simona 1992; M. Simona, pers. communication). The absence of the two species of Aulacoseira (formerly included in the genus Melosira) from the investigations carried out during the 1950s does not find sufficient support because Merlo \& Mozzi (1963) reported the occurrence of Melosira at the generic level. The ultimate answer to these uncertainties will come from palaeolimnological studies on deep lake sediments; however, preliminary analyses attested the presence of Aulacoseira in sediments dated around the 1950s (A. Marchetto, pers. communication).

Despite some unavoidable taxonomic and methodological uncertainties, the comparison of the recent results with those obtained at the beginning and before the 1970s gives signs of environmental changes. To summarise: the more evident and documentable differences seem to indicate that, with the speeding up of eutrophication processes during the 1960 s and the 1970 s, dense populations of $P$. rubescens/ag. were established and the beginning of a large development of Conjugatophyceae (mainly Mougeotia) took place. With the progression of eutrophication towards the mesotrophic levels of the 1990s, other cyanobacteria ( $P$. limnetica and $A$. lemmermannii) became part of the subdominant fraction of the phytoplankton community. All in all, these results may aid to decipher the trophic adaptability, within the range comprised between the oligotrophy and mesotrophy, of the most abundant species so far identified since the 1950s in Lake Garda. F. crotonensis, A. formosa, $C$. hirundinella and Dinobryon spp. show high adaptability and may be considered as eurytrophic species. P. rubescens/ag. and Mougeotia sp. have their optimum conditions for growth beginning from oligo-mesotrophy, whereas $A$. lemmermannii, $P$. limnetica and $C$. aciculare are indicative of higher trophic conditions that, in Lake Garda, coincide with mesotrophy. If considered in the framework of research in deep lakes, these long-term comparisons indicate that the trophic character of some algal associations described by Reynolds (1997) and reported in section 5.1 should be reconsidered for this typology of lakes. Besides the wider trophic range characterising the spring and summer groups, it should be stressed that a conspicuous presence of $F$. crotonensis, if not followed by a substantial contribution of other indicator species, does not necessarily indicate eutrophic conditions. Moreover, P. rubescens/ag. should be indicated as an abrupt sign of the early stages of eutrophication in the deep subalpine lakes (e.g. Ravera \& Vollenweider 1968). In general, the Association R, which includes Planktothrix, Planktolyngbya and Limnotrichoideae, should be considered typical of an ample trophic spectrum, from oligo-mesotrophy to eutrophy.

\section{CONCLUSIONS}

The studies carried out from 1998 to 2000 in Lake Garda have revealed a phytoplankton community largely characterised by the seasonal alternation of three 
species belonging to the diatoms ( $F$. crotonensis from late winter and spring to early summer and/or autumn), Conjugatophyceae (Mougeotia sp., with higher abundances during the stratification months) and cyanobacteria (filaments of the $P$. rubescens/agardhii complex, particularly abundant in summer and autumn). These three master species are characterised by higher biovolumes and/or more regular annual development in comparison to the remaining taxa. Many of the thirty species identified as "dominants" on the basis of their contribution to the total biovolume values, have a regular and synchronous seasonal evolution in the two subbasins of the lake, contributing to the ordered and coherent temporal succession of phytoplankton assemblages. These temporal and spatial regularities arise from the high stability and resilience against perturbations that characterise the deep and large lakes. This contrasts widely with the less predictable ordered seasonal assemblages that may be found in small and shallow lakes, where the temporal sequence of the dominant species is strongly influenced by stochastic meteorological and hydrological events (Decet et al. 1996; Salmaso \& Decet 1997).

Owing to the different methodologies adopted, the study of the main modifications undergone by phytoplankton since the first seasonal studies in the $1950 \mathrm{~s}$ must be considered with great caution. In fact, one should take into account that the detection of early lake eutrophication in the western countries has often coincided with the adoption of new, efficient methodologies and higher financial support for monitoring and research. With this in mind, and limiting the analysis to the larger and biovolume-dominant taxa, it can be said that the more significant modifications of the pristine conditions of the lake are marked, during the 1970s, by the development of Oscillatoriales ( $P$. rubescens/ag.) and by the irregular increase of Conjugatophyceae (Mougeotia sp. and C. aciculare). During the 1980s, the increase of the phosphorus concentrations in the lake and the progress towards mesotrophic conditions is accompanied by the appearance of further, dense populations of cyanobacteria ( $P$. limnetica, A. lemmermannii). In contrast with these signs of alteration, $F$. crotonensis, A. formosa, C. hirundinella and Dinobryon spp. are among the most abundant taxa from the 1950s to the present.

From an analysis of the present phytoplankton community and from its changes observed along the long time trophic gradient it is possible to clarify the trophic characteristics of the main seasonal assemblages in Lake Garda and, in general, in the deep subalpine lakes. In this context, the judgment is limited to the trophic range oligotrophy-mesotrophy. Unlike the group of eurytrophic species ( $F$. crotonensis, $A$. formosa, $C$. hirundinella, Dinobryon spp.), $P$. rubescens/ag. and Mougeotia sp. become dominant beginning from oligomesotrophy. Closterium spp., P. limnetica and A. lem- mermannii seem to be indicative of increasing trophic conditions; while waiting further information (cf. 5.2), this property could also characterise Aulacoseira spp..

These judgments partly agree with the changes documented in Lake Garda during the 1990s in consequence of spring circulation events. During complete overturn and maximum replenishment of nutrients in the euphotic layers, a greater development of Mougeotia sp. and Oscillatoriales $(P$. rubescens/ag. and/or P. limnetica) was observed. From another point of view, these historical and ecological results suggest that, with progressing eutrophication, a further increase of Oscillatoriales and Nostocales during summer and/or autumn and Conjugatophyceae from spring to autumn could be expected.

\section{ACKNOWLEDGMENTS}

I wish to express my appreciation and thanks to Dr Delio Ruggiu (CNR-Istituto per lo Studio degli Ecosistemi, Verbania Pallanza) and to Prof. Eugen Rott (Institut für Botanik, Universität Innsbruck) for criticisms and helpful comments on an earlier version of the typescript. I am grateful to Prof. Paolo Cordella (Dipartimento di Biologia, Università di Padova) and to the staff of ARPAV-Verona for critical discussions and logistic support. This work was partially funded by the Veneto Region and ARPAV.

\section{REFERENCES}

Ambrosetti W. \& L. Barbanti. 1997. Alcune problematiche fisiche dei grandi laghi sudalpini. Documenta Ist. ital. Idrobiol., 61: 3-18.

Anagnostidis, K. \& J. Komárek. 1988. Modern approach to the classification system of Cyanophytes. 3-Oscillatoriales. Arch. Hydrobiol., Algol. Stud., 50-53: 327-472.

Andreoli, C. 1977. Il Lago di Garda. Distribuzione qualitativa e quantitativa del fitoplancton in un ciclo annuale (settembre 1972 - agosto 1973). Riv. Idrobiol., 16: 269-294.

APHA, AWWA \& WEF. 1989. Standard methods for the examination of water and wastewater. 17th ed. - American Public Health Association, Washington.

Barbanti, L. 1974. Morfologia della conca lacustre. In: M. Gerletti (Ed.), Indagini sul Lago di Garda. IRSA Quaderni 18, Roma: 101-115.

Bold, H.C. \& M.J. Wynne. 1985. Introduction to the Algae. Structure and reproduction. Prentice-Hall, Englewood Cliffs, N.J.: 720 pp.

Bourrelly, P. 1972. Les Algues d'eau douce. Initiation à la Systématique, I. Les Algues Vertes. N. Boubée \& Cie, Paris : $572 \mathrm{pp}$.

Bray, J.R. \& J.T. Curtis. 1957. An ordination of the upland forest communities of Southern Wisconsin. Ecol. Monogr., 27: 325-349.

Büsing. N. 1998. Seasonality of phytoplankton as an indicator of trophic status of the large perialpine 'Lago di Garda'. Hydrobiologia, 369/370: 153-162.

Calderoni, A., R. Mosello \& R. de Bernardi. 1997. Interpretazioni problematiche di alcuni processi nella fase di oligotrofizzazione del Lago Maggiore nel decennio 1988- 1997. Documenta Ist. ital. Idrobiol., 61: 33-53.

Carmichael W.W. \& I.R. Falconer. 1993. Diseases related to freshwater blue-green algal toxins, and control measures. In: I.R. Falconer (Ed.), Algal toxins in seafood and drinking water. Academic Press Limited, London: 187-209. 
Chorus, I. \& J. Bartram. 1999. Toxic cyanobacteria in water. A guide to their public health consequances, monitoring and management. E \& FN Spon, London: 416 pp.

Clarke, K.R., \& R.H. Green. 1988. Statistical design and analysis for a "biological effects" study. Mar. Ecol., 46: 213-226.

Cook G.D., E.B. Welch, S.A. Peterson \& P.R. Newroth. 1993. Restoration and management of lakes and reservoirs. Lewis Publishers: 548 pp.

Cordella, P. \& N. Salmaso. 1993. Phytoplankton communities in the southern basin of Lake Garda, Italy. Verh. int. Ver. Limnol., 25: 754-761.

D’Ancona, U., C. Mozzi \& S. Merlo. 1961. Ricerche limnologiche sul Lago di Garda. Verh. int. Ver. Limnol., 14: 838-845.

Decet F. \& N. Salmaso. 1997. Indagini preliminari sulle caratteristiche chimiche dei principali affluenti e dell'emissario del Lago di Garda. Acqua Aria, 97/7: 9197.

Decet, F., N. Salmaso \& R. Burigo. 1996. Evoluzione temporale delle caratteristiche chimiche e della comunità fitoplanctonica in un piccolo lago d'alta quota del Trentino orientale (Lago Calaita, 1605 m). Acqua Aria giu./lug. 1996: 587-593

Dow, C.S. \& U.K. Swoboda. 2000. Cyanotoxins. In: Whitton, B.A. \& M. Potts (Eds). The ecology of cyanobacteria. Their diversity in time and space. Kluwer Academic Publishers: $669 \mathrm{pp}$

Field, J.G., K.R. Clarke \& R.M. Warwick. 1982. A practical strategy for analysing multispecies distribution patterns. Mar. Ecol. Prog. Ser., 8: 37-52

Forti, A. 1902. Contributo $4^{\circ}$ alla conoscenza della Florula Ficologica Veronese. Nuova Notarisia, Serie XIII(II): 49-68; Serie XIII(III): 97-124.

Garbini, A. 1898. Alghe neritiche del Lago di Garda. Nuova Notarisia, Serie X: 3-20.

Goldman, C.R. \& A. Jassby. 1990. Spring mixing depth as a determinant of annual primary production in lakes. In: M.M. Tilzer \& C. Serruya (Eds), Large lakes. Ecological structure and function. Springer-Verlag: 125-132.

Guilizzoni, P., G. Bonomi, G. Galanti \& D. Ruggiu. 1983. Relationship between sedimentary pigments and primary production: evidence from core analyses of twelve Italian lakes. Hydrobiologia, 103: 103-106.

Harper, D.M., B. Brierley, A.J.D. Ferguson \& G. Phillips. 1999. The ecological bases for lake and reservoir management. Developments in Hydrobiology, 136 (reprinted from Hydrobiologia, volumes 395/396): 469 pp.

Humbert, J.F. \& B. Le Berre. 2001. Genetic diversity in two species of freshwater cyanobacteria, Planktothrix (Oscillatoria) rubescens and P. agardhii. Arch. Hydrobiol., 150: 197-206.

IRSA. 1974. Indagini sul Lago di Garda. IRSA Quaderni 18, Roma: 540 pp.

Kilham, P. 1971. A hypothesis concerning silica and the freshwater plankton diatoms. Limnol. Oceanogr., 16: 1018.

Kirk, J.T.O. 1994. Light and photosynthesis in aquatic ecosystems. 2nd ed. Cambridge University Press: 509 pp.

Kirchner, O. 1899. Florula Phycologica Benacensis. XXXVI Pubblicazione Civico Museo di Rovereto: $37 \mathrm{pp}$.

Komarková-Legnerová, J. \& G. Cronberg. 1992. New and recombined filamentous Cyanophytes from lakes in South Scania, Sweden. Arch. Hydrobiol., Algol. Stud., 67: 21-31.

Komarková-Legnerová, J. \& P. Eloranta. 1992. Planktic bluegreen algae (Cyanophyta) from Central Finland (Jyväskylä region) with special reference to the genus Anabaena. Arch. Hydrobiol., Algol. Stud., 67: 103-133.

Kruskal, J.B. \& M. Wish. 1978. Multidimensional scaling. Sage Publications, Beverly Hills and London: 93 pp.
Lampert, W. \& U. Sommer. 1997. Limnoecology: the ecology of lakes and streams. Oxford-University-Press-Incorporated, New York: $382 \mathrm{pp}$.

Lehman, J.T. 1988. Selective herbivory and its role in the evolution of phytoplankton growth strategies. In: C.D. Sandgren (Ed.), Growth and reproductive strategies of freshwater phytoplankton. Cambridge University Press, Cambridge: 369-387.

Lorenzen, C.J. 1967. Determination of Chlorophyll and- PheoPigments: spectrophotometric equations. Limnol. Oceanogr., 12: 343-346.

Lund, J.W.G., C. Kipling, \& E.D. Le Cren. 1958. The inverted microscope method of estimating algal numbers and the statistical basis of estimations by counting. Hydrobiologia, 11: $143-170$.

Magurran, A.E. 1988. Ecological diversity and its measurement. Croom Helm, London: 179 pp.

Marchesoni, V. 1952. Ricerche orientative sulla microflora pelagica del Garda. Studi Trentini di Scienze Naturali, 29: 85-109.

Merlo, S. e C. Mozzi. 1963. Ricerche limnologiche sul Lago di Garda. Arch. Oceanogr. Limnol., 13: 1-125.

Micheletti, S., F. Schanz \& A.E. Walsby. 1998. The daily integral of photosynthesis by Planktothrix rubescens during summer stratification and autumnal mixing in Lake Zurich. New Phytol., 139: 233-246.

Negri, A. \& C. Morazzoni. 1990. Analisi dei risultati: il fitoplancton. In: G. Chiaudani \& G. Premazzi (Eds), Il Lago di Garda. Evoluzione trofica e condizioni ambientali attuali. Centro Comune di Ricerca, Commissione delle Comunità Europee. EUR12925IT: 193 pp.

OECD. 1982. Eutrophication of waters. Monitoring, assessment and control. OECD, Paris : $154 \mathrm{pp}$.

Pasini, P.G. 1992. Lago di Garda. Trent'anni di turismo. Civiltà Gardesana, Studi ed Esperienze, 6: 96 pp.

Polli, B. \& M. Simona. 1992. Qualitative and quantitative aspects of the evolution of the planktonic populations in Lake Lugano. Aquat. Sci., 54: 303-320.

Ravera, O. \& R.A. Vollenweider. 1968. Oscillatoria rubescens D.C. as an indicator of Lago Maggiore Eutrophication. Schweiz. Z. Hydrol., 30: 374-380.

Reynolds, C.S. 1984. The ecology of freshwater phytoplankton. Cambridge University Press, Cambridge: 384 pp.

Reynolds, C.S. 1997. Vegetation processes in the pelagic: a model for ecosystem theory. Ecology Institute, Oldendorf: $371 \mathrm{pp}$.

Reynolds, C.S., V.L.M. Huszar, C. Kruk, L. Naselli-Flores \& S. Melo. 2002. Towards a functional classification of the freshwater phytoplankton. J. Plankton Res.: in press.

Rott, E. 1981. Some results from phytoplankton counting intercalibrations. Schweiz. Z. Hydrol., 43: 34-62.

Ruggiu, D. 1983. Caratteristiche e comportamento del fitoplancton nei laghi profondi sudalpini. In: W. Ambrosetti, L. Barbanti, R. Mosello, A. Rolla \& D. Ruggiu (Eds), Mescolamento, caratteristiche chimiche, fitoplancton $e$ situazione trofica nei laghi profondi sudalpini. C.N.R.P.F. "Promozione della Qualità dell'Ambiente", AQ/2/20: 105-143.

Ruggiu, D. 1989. An evaluation of phytoplankton communities of Lago Maggiore typifying the stages of its trophic evolution. Mem. Ist. ital. Idrobiol., 46: 89-102.

Ruggiu, D. 2002. Phytoplankton in deep Italian lakes: introductory remarks. J. Limnol., 61(1): 93-94.

Ruggiu, D. \& R. Mosello. 1984. Nutrient levels and phytoplankton characteristics in the deep southern subalpine lakes. Verh. int. Ver. Limnol., 22: 1106-1112.

Ruggiu D., G. Morabito, P. Panzani \& A. Pugnetti. 1998. Trends and relations among basic phytoplankton characteristics in the course of the long-term oligotrophication of Lake Maggiore (Italy). Hydrobiologia, 369/370: 243-257. 
Ryding S.-O. \& W. Rast (Eds). 1989. The control of eutrophication of lakes and reservoirs. UNESCO \& The Partenon Publishing Group, Paris: 314 pp.

Salmaso, N. 1996. Seasonal variation in the composition and rate of change of the phytoplankton community in a deep subalpine lake (Lake Garda, Northern Italy). An application of nonmetric multidimensional scaling and cluster analysis. Hydrobiologia, 337: 49-68.

Salmaso, N. 2000. Factors affecting the seasonality and distribution of cyanobacteria and chlorophytes: a case study from the large lakes south of the Alps, with special reference to Lake Garda. Hydrobiologia, 438: 43-63.

Salmaso, N. \& F. Decet. 1997. Seasonal and interannual changes of chemical characteristics and phytoplankton in a mountain lake of the eastern Italian Alps (Lake Calaita, Trentino). Int. Rev. ges. Hydrobiol., 82: 15-31.

Salmaso N. \& F. Decet. 1998. Interactions of physical, chemical and biological processes affecting the seasonality of mineral composition and nutrient cycling in the water column of a deep subalpine lake (Lake Garda, Northern Italy). Arch. Hydrobiol., 142: 385-414.

Salmaso, N. \& L. Naselli-Flores. 1999. Studies on the zooplankton of the deep subalpine Lake Garda. J. Limnol., 58: 66-76.

Salmaso, N., F. Cavolo \& P. Cordella. 1994. Fioriture di Anabaena e Microcystis nel Lago di Garda. Eventi rilevati e caratterizzazione dei periodi di sviluppo. Acqua Aria, 1 (gen.): 17-28

Salmaso, N., F. Decet \& P. Cordella. 1999. Understanding deep oligotrophic subalpine lakes for efficient management. Hydrobiologia, 395/396: 253-263.

Salmaso, N., F. Decet \& P. Cordella. 2001b. Spring mixing depth affects the interannual variations in phytoplankton abundance and composition in deep lakes. A case study from Lake Garda (Northern Italy). Verh. Int. Ver. Limnol.: in press.

Salmaso, N., F. Decet \& R. Mosello. 1997b. Chemical characteristics and trophic evolution of the deep subalpine Lake Garda (Northern Italy). Mem. Ist. ital. Idrobiol., 56: 51-76.

Salmaso, N., F. Decet, G. Franzini \& P. Cordella. 2001a. Evoluzione trofica del Lago di Garda in relazione alla completa circolazione delle acque del 1999 e 2000. Atti Associazione Italiana Oceanologia e Limnologia, 14: 109123.

Salmaso, N., F. Decet, M. Manfrin \& P. Cordella. 1997a. Ricerche limnologiche sul Lago di Garda (1991-1996). Documenta Ist. ital. Idrobiol., 61: 173-199.

Saraceni, C. \& D. Ruggiu. 1974. Techniques for sampling water and phytoplankton. In: R.A. Vollenweider (Ed.), $A$ Manual on methods for measuring Primary Production in Aquatic Environments. IBP Handbook 12, Blackwell, Oxford: 5-7.

Sommer, U. 1987. Factors controlling the seasonal variation in phytoplankton species composition. A case study for a deep, nutrient rich lake. Prog. Phyc. Res., 5: 123-178.

Sommer, U., Z.M. Gliwicz, W. Lampert \& A. Duncan. 1986. The PEG-model of seasonal succession of planktonic events in fresh waters. Arch. Hydrobiol., 106: 433-471.

Talling, J.F. 1971. The underwater light climate as a controlling factor in the production ecology of freshwater phytoplankton. Mitt. int. Ver. Limnol., 19: 214-243.

Tilman, D. 1977. Resource competition between planktonic algae: an experimental and theoretical approach. Ecology, 58: $338-348$.

Tilman, D. \& S.S. Kilham. 1976. Phosphate and silicate uptake and growth kinetics of the diatoms Asterionella formosa and Cyclotella meneghiniana in batch and semicontinuous culture. J. Phycol., 12: 375-383.

Trimbee, A.M. \& E.E. Prepas. 1987. Evaluation of total phosphorus as a predictor of the relative biomass of blue-green algae with emphasis on Alberta lakes. Can. J. Fish. aquat. Sci., 44: 1337-1342.

Walsby, A.E., A. Avery \& F. Schanz. 1998. The critical pressures of gas vesicles in Planktothrix rubescens in relation to the depth of winter mixing in Lake Zurich, Switzerland. J. Plankton Res., 20: 1357-1375.

Watson, S.B., E. McCauley \& J.A. Downing. 1997. Patterns in phytoplankton taxonomic composition across temperate lakes of differing nutrient status. Limnol. Oceanogr., 42: 487-495.

Wilkinson, L. 1990. SYSTAT: the system for statistics. SYSTAT, Inc., Evanston, 677 pp. 